\title{
WINTERING BEES IN CANADA
}

$\mathrm{BY}$

C. B. GOODERHAM, B.S.A.

DOMINION APIARIST

DOMINION OF CANADA

DEPARTMENT OF AGRICULTURE

BULLETIN NO. 74-NEW SERIES

DIVISION OF BEES

DOMINION EXPERIMENTAL FARMS

21 Agriculture $\begin{array}{ll}\text { Canadian Agriculture Library } \\ \text { Canada } & \text { Bibliothèque canadiennedel'agri }\end{array}$

Bibliothèque canadienne de l'agriculture Ottawa K1A OC5

630.4

C212

B 74

n.s.

1926

c. 2

Published by direction of the Hon. W. R. Motherwell, Minister of Agriculture,

$$
\text { Ottawa, } 1926
$$




\section{DOMINION EXPERIMENTAL FARMS BRANCH}

\section{PERSONNEL}

Director, E. S. Archibald, B.A., B.S.A.

Dominion Field Husbandman...................... S. Hcpkins, B.S.A., M.S.

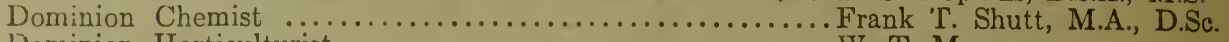

Dominion Horticulturist .......................... T. Macoun.

Dominion Cerealist .............................. Newman, B.S.A.

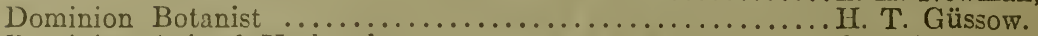

Dominion Animal Fiusbandman..................... B. Rothwell, B.S.A.

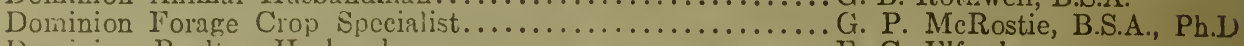

Dominion Poultry Husbandman.................... C. Elford.

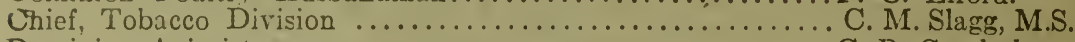

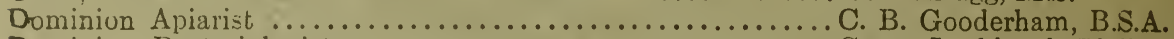

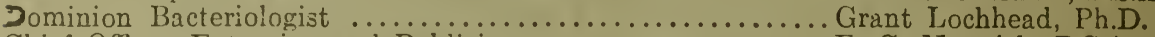

Chief Officer, Extension and Publicity................... Nunnick, B.S.A.

Chief Supervisor of Illustration Statians................ John Fixter.

Economic Fibre Specialist......................... J. Hutchinson.

\section{ALBERTA}

Superintendent, Experimental Station, Lacombe, Alta., F. H. Reed, R.S.A.

Superintendent, Experimental Station, Lethbridge, Alta., W. H. Fairfield, M.Sc.

Superintendent, Experimental Sub-station, Bearerlodge, Alta., W. D. Albright.

Superintendent, Experimental Sub-station, Fort Vermilion, Alta., Robt. Jones.

\section{BRITISH COLUMBIA}

Superintendent, Experimental Farm, Agassiz, B.C., W. H. Hicks, B.S.A.

Superintendent, Experimental Station, Summerland, B.C., W. T. Hunter, B.S.A.

Superintendent, Experimental Station, Invermere, B.C., R. G. Newton, B.S.A.

Superintendent, Experimental Station, Sidney, B.C., E. M. Straight, B.S.A.

\section{MANITOBA}

Superintendent, Experimental Farm, Brandon, Man., M. J. Tinline, B.S.A. Superintendent, Experimental Station, Morden, Man., W. R. Leslie, B.S.A.

\section{SASKATCHEWAN}

Superintendent, Experimental Farm, Indian Head, Sask., W. H. Gibson, B.S.A.

Superintendent, Experimental Station, Rosthern, Sask., W. A. Munro, B.A., B.S.A.

Superintendent, Experimental Station, Scott, Sask., Victor Matthews, B.S.A.

Superintendent, Experimental Station, Swift Current, Sask., J. G. Taggart, B.S.A.

\section{NEW BRUNSWICK}

Superintendent, Experimental Station, Fredericton, N.B., C. F. Bailey, B.S.A.

\section{NOVA SCOTIA}

Superintendent, Experimental Farm, Nappan, N.S., W. W. Baird, B.S.A.

Superintendent, Experimental Station, Kentville, N.S., W. S. Blair.

\section{PRINCE EDWARD ISLAND}

Superintendent, Experimental Station, Charlottetown, P.E.I., J. A. Clark, B.S.A.

\section{ONTARIO}

Central Experimental Farm, Ottawa, Ont.

Superintendent, Experimental Station, Kapuskasing, Ont., S. Ballantyne.

Superintendent, Experimental Station, Harrow, Ont., D. D. Dirges, B.S.A., M.Sc.

\section{QUEBEC}

Superintendent, Experimental Station, Cap Rouge, Que., G. A. Langelier. D.Sc.A.

Superintendent, Experimental Station, Lennoxville. Que., J. A. McClary.

Superintendent, Fxperimental Station, Ste. Anne de la Pocatière, Que., J. A. Ste. Marie, B.S.A

Superintendent, Experimental Station, La Ferme, Que., P. Fortier, Agr.

Superintendent, Experimental Station, Farnham, Que., J. E. Montreuil, B.S.A. 


\section{TABLE OF CONTENTS}

PAGE

Factors essential for successful wintering.. $\ldots \ldots \ldots \ldots \ldots$

How bees winter.$\ldots \ldots \ldots \ldots \ldots \ldots \ldots$

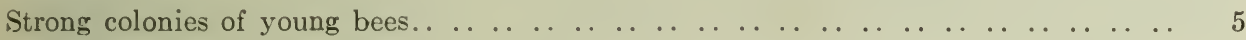

Abundant supply of wholesome stores.. . . . . . . . . . . . . . . . . . . . . 6

Protection from the cold.$\ldots \ldots \ldots \ldots \ldots$

Wintering in the cellar.. $\ldots \ldots \ldots \ldots \ldots \ldots$

Wintering outside.$\ldots \ldots \ldots \ldots \ldots \ldots \ldots \ldots \ldots \ldots \ldots$

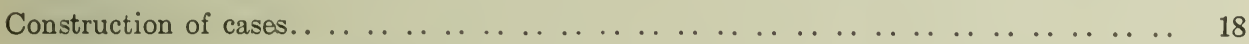

Outdoor versus cellar wintering. $\ldots \ldots \ldots \ldots \ldots$

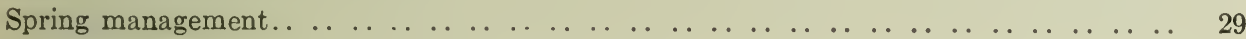

Summary . . . $\ldots \ldots \ldots \ldots \ldots \ldots$ 


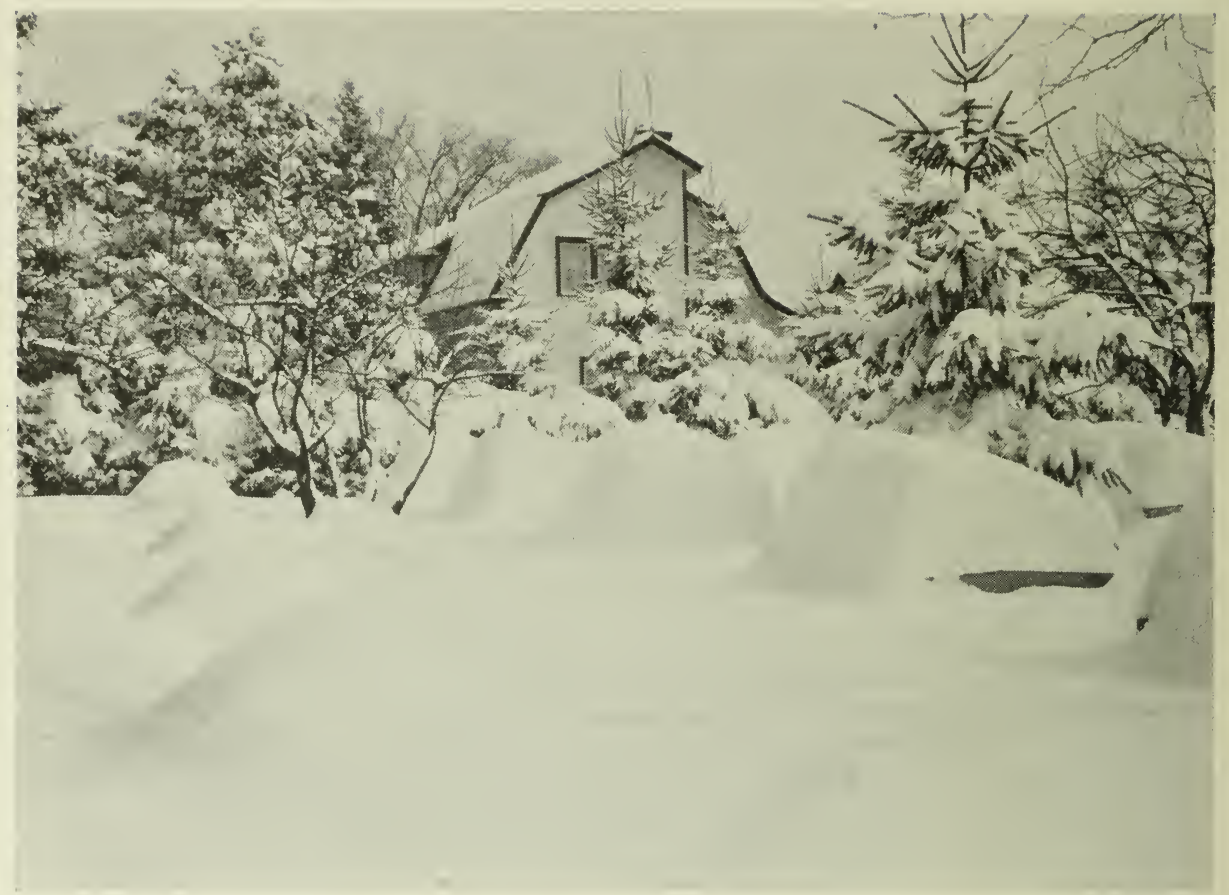

Part of apiary at the Central Experimental Farm, Ottawa. Cases well blanketed with snow and protected from the wind. 


\section{WINTERING BEES IN GANADA}

Beekeeping has become an important industry in Canada. From coast to coast bees are being kept in larger numbers each year, and especially is this true of the Western Provinces. One of the vital factors $m$ the building up of this industry is the preservation of the bees during the winter. There die in Canada every winter large numbers of colonies which a little more care and better management would have saved. In addition, many more are so seriously weakened, also through lack of care, that they fail to build up in time for the main honey flow. It is far better to give the bees the necessary care in the fall than it is to find empty and depleted hives in the spring and making the bees that survive spend the best part of the summer in filling them again. The remarkably high yields of first-grade honey in most parts of Canada should offer enough financial inducement to prepare the bees for the winter with the utmost care. To put off the preparation until the cold weather has arrived is to court disaster, because exposing the bees to cold early in the winter and disturbing them during the cold weather are injurious.

The long, cold winter in most parts of Canada is not so hard on bees as might be imagined; and in some respects wintering is easier than in a milder climate. This is because the bees rest more completely during the winter months instead of wearing themselves out with useless activity. Few conditions are harder on the bees than very mild weather during the late winter when they wear themselves out and die by the thousands trying to raise a little brood" and flying out to visit the early flowers in chilly and changeable weather. These conditions occur to some extent on Vancouver island. In most parts of Canada, however, the winter rest continues until sometime in April. Then come quickly the long warm days; the bees build up rapidly; and the colonies become strong in a remarkably short time.

\section{FACTORS ESSENTIAL FOR SUCCESSFUL WINTERING}

We have learned that in Canada there are three important factors necessary for successful wintering, the neglect of any one of which will either cause the death of the colony or so seriously weaken it that it becomes an unprofitable producer. These three factors are:-

1. Strong (that is to say, populous) colonies, consisting mainly of young bees.

2. An abundance of wholesome stores; and

3. Adequate protection from cold and changeable temperatures.

The successful wintering of bees in Canada depends mainly on these three conditions, and it is within the power of the beekeeper to supply them.

\section{HOW BEES WINTER}

Bees do not hibernate in the true sense of the word. When it becomes cold, they form a compact cluster, and the bees in the heart of the cluster generate heat by muscular activity. This activity, of course, necessitates the consumption of stores in proportion to the amount of energy expended. The bees on the outside of the cluster act as insulators to prevent the escape of the heat generated. Dr. Phillips and G. S. Demuth have shown that when the temperature within the hive hovers between 69 and 57 degrees Fahrenheit, the bees 
remain quiet on the combs; but as soon as the temperature falls to 57 degrees or lower a cluster is formed and heat generated. The colder the hive gets, the greater will be the amount of heat required to keep up the temperature of the hive. Should the cluster be a small one, there will be fewer bees for heat production and insulation of the cluster, and these few will have to work harder to produce the necessary heat. Excessive heat production is apt to start the bees producing brood, which is usually fatal to a colony during winter when the bees are unable to fly. The greater the number of bees within the colony, the smaller the amount of work required from each individual bee, provided that stores and protection are equal. It is, therefore, impossible to get a colony too strong for the winter: the tendency is to err in the opposite direction.

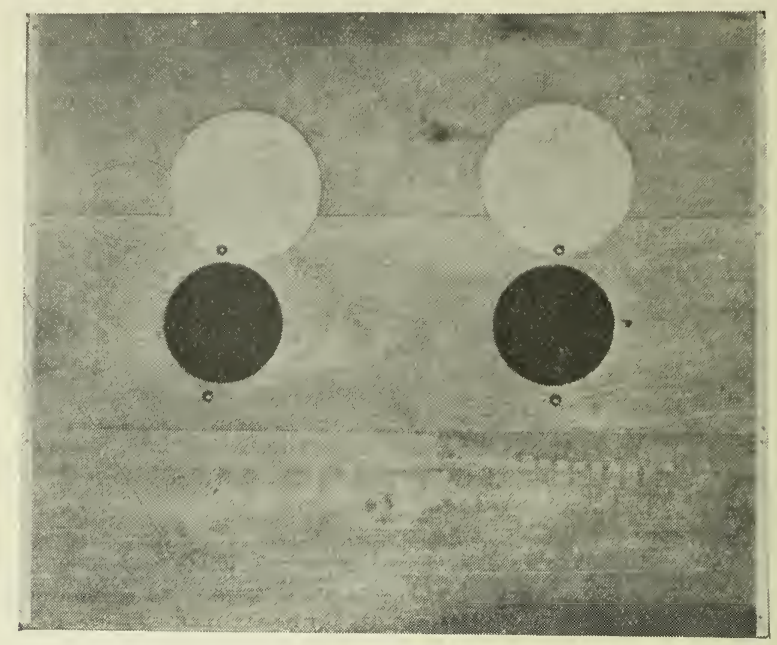

FIG. 1.-Honey-board feeder.

As a result of the consumption of food, waste matter collects in the intestines. Healthy bees discharge this waste matter only during flight, but in many parts of Canada the winter is too cold for bees to fly for four, five or even six months. This long period makes it of the greatest importance that the bees be so well protected from the cold that they will not need to consume much food; also that the food be perfectly wholesome and as free as possible from indigestible matter. If the cluster is small or the bees have been exposed to severe cold during the early part of the winter, there will be a heavy consumption of stores and a rapid accumulation of fæces which, in turn, brings about a condition known as dysentery, that shows itself in excessive heat production and great restlessness, many of the affected bees leaving the hive as soon as the temperature rises a little, but while it is too low for a favourable flight so that they die outside of the hive in large numbers. Usually, when suffering from dysentery, the abdomen of the bee is distended and the combs and front of the hive are badly soiled with brown fæces. In a bad case of dysentery the colony usually dies before spring or it survives with so few bees and these so enfeebled that it fails to build up and become profitable.

Since bees wear and age just as surely, though not so rapidly, during the winter as in the summer and a maximum population is needed to survive far. into the spring in order to raise a large quantity of brood, then it is important that the bees going into winter quarters should be young. These facts explain 
why successful wintering depends principally upon the three conditions previously mentioned and which we may repeat: populous colonies, consisting mainly of young bees; plenty of wholesome stores; and adequate protection from the cold.

\section{STRONG COLONIES OF YOUNG BEES}

By strong colonies is meant populous colonies with becs enough to cover at least eight full-sized Langstroth frames just before the weather is cold enough for clustering closely. Although colonies weaker than this may live through the winter they are seldom strong enough when brought out in the spring to

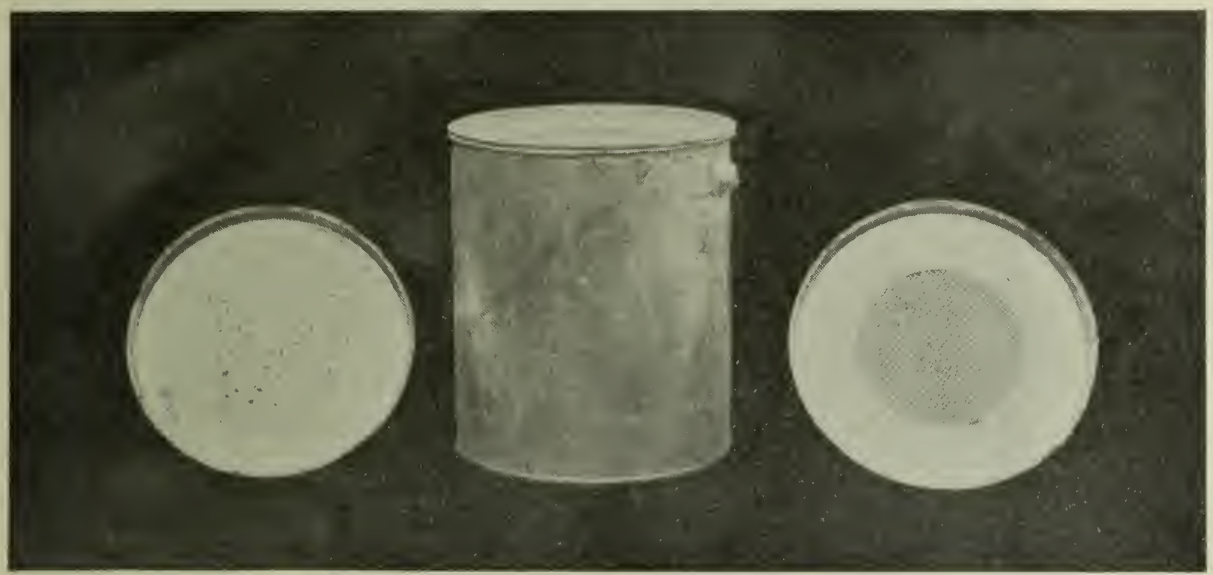

Fig. 2.-Ten-pound honey-pail feeder. (Left) Cover perforated with fine nail. (Right) Cover fitted with perforated zinc.

build up into good producing colonies. Young bees are those that have done little or no field work, but they should have had at least one good flight before winter sets in. Bees emerge from their cells with a given amount of energy which, if used up in work, shortens their lives; hence, if bees have done much work before entering on their winter's rest, they are not likely to survive the winter, much less to live long enough to be replaced with young bees in the spring. The bees that are to live through the winter will be reared principally in August and September and the best way to get them in large numbers is to have in the hive a queen reared the same season, this queen to commence laying about August 1. This means that she must be reared during June or early July, during the honey-flow from clover, and no better conditions for the rearing of queens exist than those found in Canada at this time. By having a good prolific queen in the hive by the first of August, ample time is given for her to produce a strong force of bees before normal brood production ceases in the fall. Not only will the colony containing a young queen raise more bees for the winter than one containing an old queen, but the young queen will be more prolific and profitable the following spring. It may not, however, be convenient to requeen every colony at the time specified, nor is it necessary to do so if the old queen is still very prolific. Such a queen may be left with the colony and be replaced later, but no weak or failing queen should be left with a colony later than the first of August unless she has shown exceptional characteristics 
that make her desirable as a breeder and is required as such. Leaving old queens in the hives during the fall too often results in the following:-

1. Supersedure too late in the fall for the young queen to get mated; thus the colony is found to contain a drone-producing queen the following spring.

2. The old queen may perish during the winter or early spring leaving the colony hopelessly queenless.

3. An old queen may suddenly fail in the spring and become superseded at a time when the highest brood production is needed, thus causing a check in brood rearing.

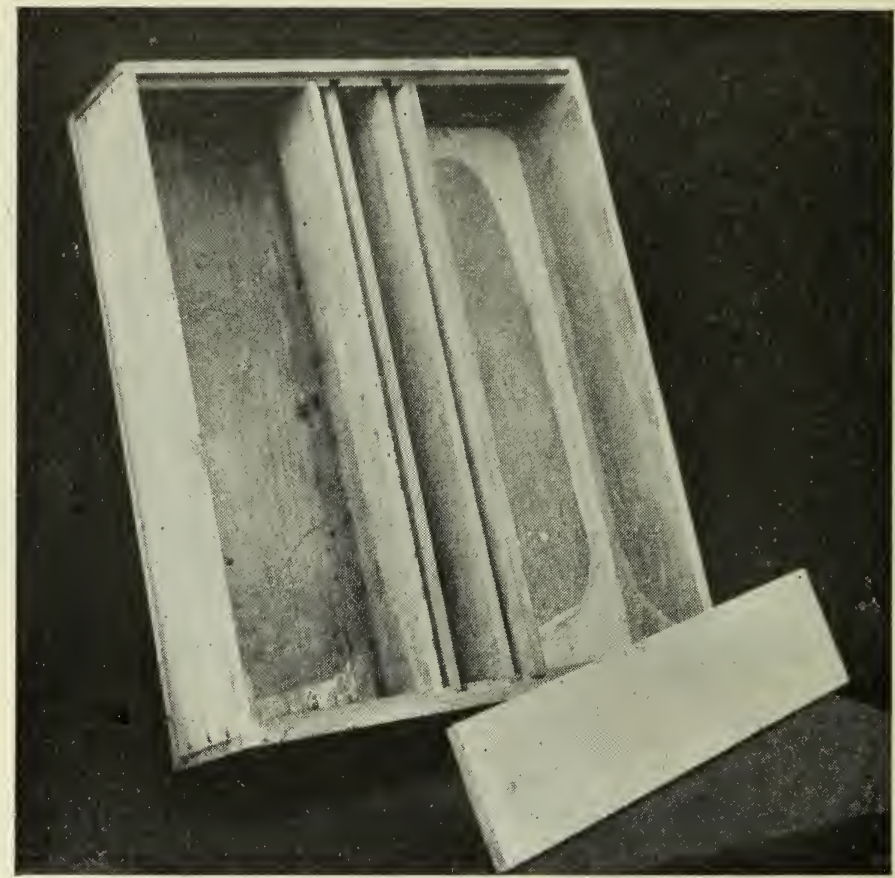

FIG. 3.-Miller feeder.

Colonies that are not strong in the fall should be united until they are of proper strength for wintering. It may happen that some of the weak colonies contain young queens that the beekeeper would like, if possible, to keep until the following spring in case some queens of strong colonies may be lost or injured through accident. Where such a desire exists, such queens may be saved by bringing together in one hive, but with a tight-fitting division-board between them, two of the colonies that are too weak for successful wintering by themselves and yet have enough bees to cover four or five Langstroth frames. Such double colonies will winter safely either in a cellar or wintering cases.

\section{AN ABUNDANT SUPPLY OF WHOLESOME STORES}

It is fortunate that, as a rule, the honeys of the north are more wholesome for wintering than those of the south. This is perhaps because most of it is gathered from the clovers.

Clover honey is an excellent winter food for bees and in localities where the honey stored comes chiefly from alsike and white clovers, the bees winter 
vell on it in spite of extremely long confinement to winter quarters. Buckwheat honey has also given good results for wintering in the region where this plant yields abundantly. On the other hand, dandelion has proven fatal as a winter food for bees. Some of the honeys gathered in the late summer are also unwholesome, especially'in certain marsh districts in the Maritime Provinces. The honey of hard maple has also been complained of by beekeepers in districts where such is gathered in large quantities. Dandelion honey and honey reported from the hard maple granulate in the combs so hard that wintering bees are unable to use it. At Ottawa, honey gathered from sweet clover occasionally causes considerable loss in bees during the winter. In southern Alberta, where the bulk of the honey is gathered from alfalfa, considerable

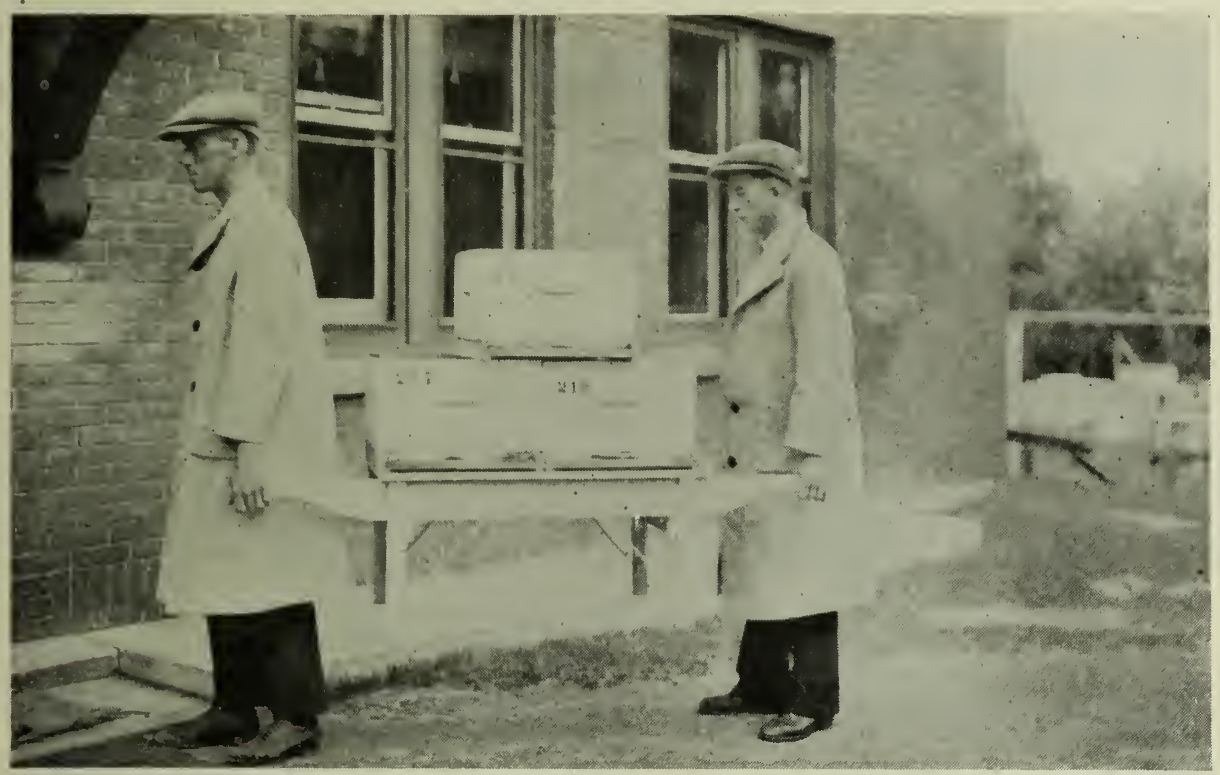

Fig. 4.-Carrying bees into cellar at Ottawa.

losses have occurred because of the honey granulating solidly in the combs. In some localities, especially in parts of the north, the bees are sometimes unable to ripen and seal the honey gathered from aster and other late sources, owing to the rapid onset of cold weather. Such unripe honey is liable to ferment and in this condition will quickly cause dysentery. Dysentery and death will also rapidly follow the consumption of winter stores consisting largely of fruit juices gathered by the bees in the fall from over-ripe or damaged fruit. Honeydew, the excretion of plant-lice dropped on the leaves of trees, and gathered by the bees is also very injurious because it contains a large proportion of indigestible matter. Fortunately, it is produced and gathered less frequently and less extensively in Canada than in the south.

The best substitute for unwholesome stores is a syrup made by dissolving two parts, by measure or weight, of white granulated sugar in one part of water. This syrup can be made up in large or small quantities as necessary and should be given the bees during the latter part of September or early in October in southern Ontario, so as to give the bees ample time for storing, ripening and sealing while the weather is still warm. It is not advisable to put the feeding off too late, as the weather may change rapidly and become too cold for the bees to store enough for the winter. The syrup is best made by first heating a 
measured quantity of water and then adding to it the required amount of sugar to make a 2 to 1 solution. This solution should be stirred until all crystals of sugar are dissolved, otherwise the sugar might crystalize out after feeding. While making the syrup, some beekeepers add about one teaspoonful of tartaric acid to every 20 pounds of sugar to help inversion of the sugar and to prevent granulation. Care must be taken not to burn or scorch the sugar, as this is injurious to the bees. The syrup should be given rapidly in large feeders and preferably while it is warm. A ten-pound honey-pail with from thirty to forty fine holes punched through the cover, and inverted over the frames, makes a very convenient feeder (see fig. 2). Some beekeepers prefer to use a honeyboard, upon which to rest the feeders, over the frames. Those who use quilts

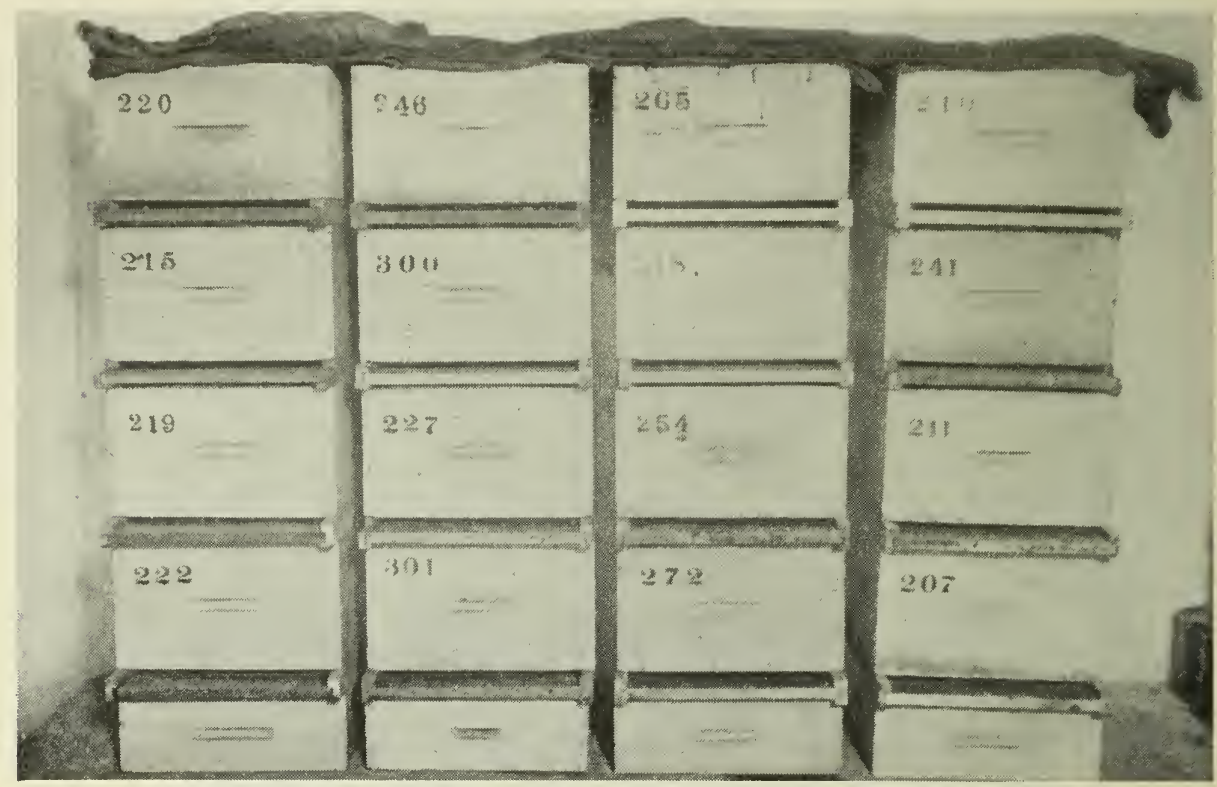

FIG. 5.-Colonies tiered up in a corner of the cellar at Ottawa.

can turn back one or more corners of the quilt according to the number of feeders used. One, two or even three of these pails filled with syrup may be given to the colony at one time. A ten-pound honey pail holds approximately nine pounds of syrup ( 6 of sugar and 3 of water). The advantage of the honeypail feeder is that the bees do not have to leave the brood chamber to obtain the syrup as is the case with most other feeders.

In most localities, the honey left in the hive after the supers are removed in the fall is from mixed sources and of doubtful quality and is also usually deficient in quantity. A good and widespread practice is to feed to each colony enough sugar syrup to bring the stores up to the required amount for the winter supply. Even if a colony has stored enough honey for the winter, it is a wise plan to give it at least ten or fifteen pounds of syrup. The syrup is stored nearest to the winter cluster and is the first to be consumed and thus the accumulation of faeces is delayed. For every pound of stores required by the colony one pound of sugar made into syrup must be given. In fact a pound of sugar does not provide a full pound of stores for winter. Experiments at Ottawa show that from a pail of syrup consisting of 6 pounds of sugar and 3 pounds of water, the bees only store about $5 \frac{1}{2}$ pounds on the average. 
The quantity of stores left or provided should be estimated liberally. It is far better to find in the spring strong colonies with a surplus of stores than to find the colonies dead from starvation. The quantity of stores a colony will consume varies considerably, and when the stores are poor may be twice as much as when they are good. Heavy consumption of stores also results from other causes, such as undue disturbance or insufficient protection. Bees wintered outside may consume more stores than those wintered in the cellar, but this difference is not so much as might be imagined when the time from feeding to the time the bees are removed from their cases is considered. The most common cause of the death of colonies in winter is starvation, either through exhaustion of stores or through the stores granulating so hard as to make them unavailable to the bees. As a general statement, it may be said that at least 40 to 45 pounds of stores should either be left or given to each colony, in order that it may have enough to last from the time of feeding in the fall until there is enough new nectar available in the spring. To be safe, it is a good plan to give the bees all they will take down at feeding time. It is not safe to give just enough to carry the colony through the winter and trust to spring feeding, for although actual winter consumption may not reach 20 pounds, large amounts are needed when brood-rearing commences in the spring, and this usually occurs before the weather is suitable for spring feeding. Therefore, it is better to give the extra food in the fall and thus avoid early spring manipulations that are injurious to the colony. Any shortage of stores during the spring will retard brood production.

Since the ordinary factory-made, single-walled Langstroth hive with bees and combs, but without its cover, weighs, if dry, between 30 and 40 pounds, such a hive, when ready for the winter, should weigh between 70 and 80 pounds. In addition to the stores left for the winter, the beekeeper will be well advised to set aside a number of well-filled combs from the previous crop for emergency use in the spring.

\section{PROTECTION FROM THE COLD}

There are two ways of protecting bees during the winter: outside in cases filled with packing material, and in cellars. Generally speaking, both methods are satisfactory almost anywhere in Canada, but in many places the most important factors in deciding which method to adopt are convenience and cost. If the beekeeper has a fairly dry cellar that can be kept dark and that is well insulated from changes in outdoor temperatures, he can save himself the cost of building cases and the labour of packing the bees. If, on the other hand, the apiary (perhaps an out-apiary) is some distance from the beekeeper's residence, is well sheltered from winds, and no suitable cellar be available, cases may be built and the bees safely packed in them. Both methods of giving protection are widely used, but outdoor wintering appears to be gaining in favour, because of the extra protection afforded the bees during the late fall and early spring and also because most cellars now used for wintering bees are unsatisfactory for that purpose. Cellar wintering may require less labour to protect and also less stores for actual wintering, but the main disadvantage lies in the fact that the bees are exposed to cold weather and sharp changes in temperature much later in the fall and again much earlicr in the spring than those wintered outside. Bees wintered outdoors not only have the advantage of this extra protection which enables them to start brood production much earlier in the spring than do cellar-rvintered bees, but they can also take early flights whenever the weather is suitable. Another fact is that the person who follows wintering outside is, on the whole, more inclined to prepare his bees better for the winter than the beekeeper who practises wintering in a cellar.

27757-2 


\section{WINTERING IN THE CELLAR}

A good bee-cellar is one in which the temperature can be easily brought to that which is most suitable for the bees and can be kept constant throughout the winter. As the bees maintain a temperature of 57 degrees $\mathrm{F}$. at the outer edge of the cluster, the temperature of the cellar should be such that the bees may maintain this degree of heat with a minimum expenditure of energy. At Ottawa it has been found that a cellar temperature of 45 to 48 degrees $\mathrm{F}$. gives the greatest degree of quietness among the bees. The cellar should also be dark, fairly dry, and provided with good means for ventilation. Two of these conditions, the steady temperature and moderate dryness, are not always easy to get

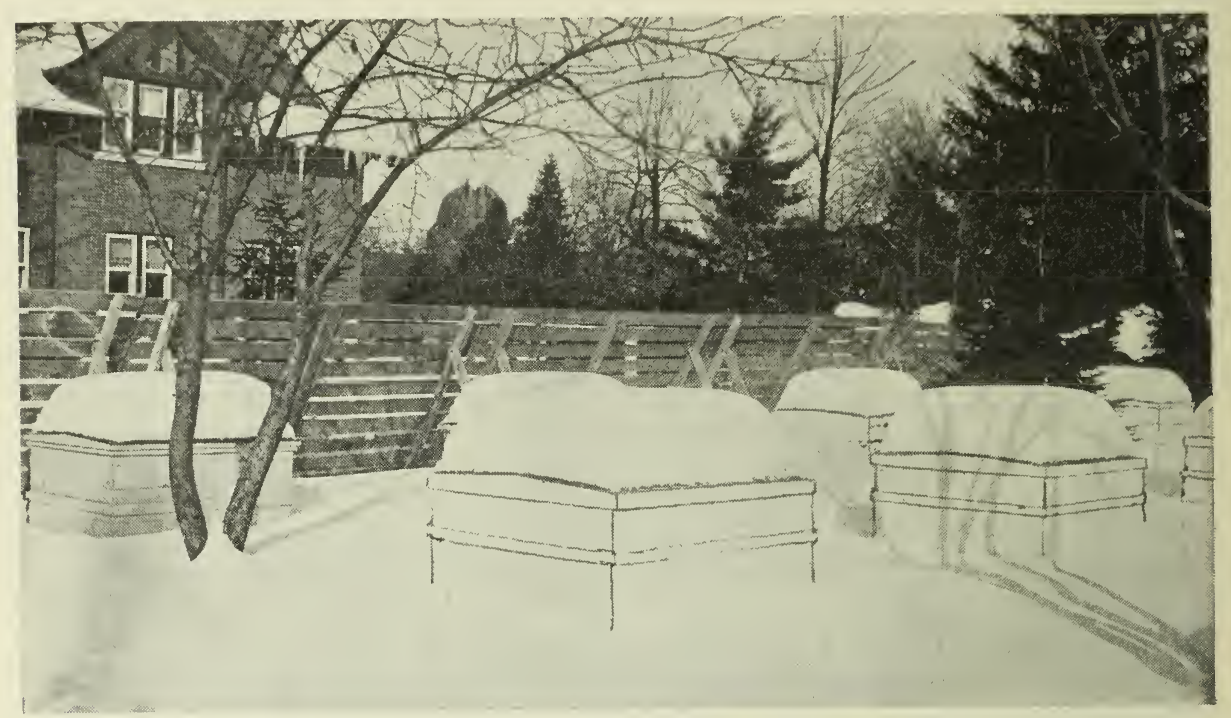

Fig. 6.-A portable wind-break on north side of yard at Ottawa.

and maintain. To secure them, two important principles in cellar construction should be observed: the cellar should be so low in the ground that it is not affected by changes in outdoor temperatures, and the ground should be well drained.

Excellent results are often obtained, especially if only a few colonies are to be wintered, by partitioning off a portion of the cellar beneath the beekeeper's residence, not too near nor too far from the furnace, because the furnace and the heated rooms above help to supply and maintain the required conditions so well that minor defects in the construction of the cellar do not matter. Although such a cellar usually provides the proper temperature anci ventilation during the coldest months of winter, the temperature is apt to risc too high during the milder weather of spring. If such a condition should occur, the cellar may be cooled off by opening the basement windows a little. The chamber for the bees should be near or against the wall of the basement, and this part of the wall may be banked on the outside with earth to above the level of the chamber. The bees should not be placed in the room used for storing roots or vegetables.

Where the cellar is specially excavated for the bess, concrete is a good material for the floor and walls unless the location is a rery dry one, when an earth floor is perhaps the best. It is a good plan to build over the cellar the house that is to be used for apiary work, such as for extracting honey or storing supplies. If the rooms above the cellar are not heated during the winter, it will 
be necessary to have the ceiling of the cellar double-walled with a large interspace filled with sawdust or other non-conductor of heat. The height from floor to ceiling of the bee-cellar should be about six and a half feet, and the ceiling should be well below the surface of the ground. For good drainage and insulation, the side of a hill is a desirable place for building a bee-cellar and in such a location the cellar may be constructed so that a door can be placed at the floor level for easily bringing the bees in and out. Where a cellar is so constructed, to prevent the escape of heat and to provide better insulation from the outside, there should be two doors provided with a vestibule between them. To carry off the moisture produced by the bees and to supply ventilation, a shaft or chimney should be provided. This chimney may open into the upper chamber.

For every volume of honey consumed, the bees give off an amount of moisture which, if condensed, would make an approximately equal volume of water. If the air of the cellar is already laden with moisture, the moisture given off by the bees would condense within the hive--a condition that, if it occurs to any great extent and is long continued, is liable to do great injury to the bees. Such a condition usually occurs when the cellar is too cold, as air at zero can hold only one-sixth the weight of water that air at 45 degrees can hold.

Very dry conditions are also unfavourable, especially towards the end of a long winter when more or less dysentery has developed. The stores may lose so much of their water that the bees are unable to remove them from the cells and the colony may die in consequence. This condition occurs most frequently in connection with granulated stores, but it sometimes takes place with stores that do not granulate, such as buckwheat honey and sugar syrup. Soft candy given to a colony suffering from this trouble will harden, anc' thus it too becomes unavailable for food and the colony may starve. In Canada, ventilated cellars are liable to become very dry in cold weather because of the small amount of moisture contained in the outside air that is drawn in. This is more true of the Prairie Provinces than of the Maritime Provinces or the coastal region of British Columbia, hence, considerable care must be exercised in providing proper ventilation. In addition tr, the shaft or chimney outlet, the cellar should be provided with an air-intake opening at or near the floor and on the opposite side from the outlet. This provides excellent ventilation and the cellar may be kept dry. The main trouble with such a system of ventilation, however, is that it usually works most when least required and least when most wanted. In cold weather, when warm, moist air is needed, cold, dry air is drawn in strongly through the smallest opening; while in mild weather, when cool air is desirable, very little air will enter through the largest opening. Therefore, the ventilators need to be kept closed during cold weather and wide open during mild weather, and thus they need frequent adjusting in regions where mild weather alternates with cold during the winter. It would, therefore, be advisable to construct both intake and outlet so that they may be opened or closed when desired. The necessity for frequently adjusting ventilatcrs in a region where cold alternates with mild weather, especially in cellars not deep in the ground, constitutes a serious disadvantage to wintering in such cellars and cellar wintering has been largely replaced by outside wintering.

For convenience, we have spoken of the temperature and humidity of the bee-cellar, but it is the temperature and humidity of the air in the hive surrounding the bee cluster that is of most importance. If the air in the cellar is cool and dry, the air within the hive may be warmed and moistened to some extent by reducing the entrance of the hive and by placing a warm impervious cover over the hive. It is the practice of some Canadian beekeepers to keep the cellar temperature rather low, in some cases below 40 aegrees $F$., because it is sometimes found that at a higher temperature the bees become restless, especially towards spring. This restlessness, however, as has been shown, does not originate from the high temperatures, but from other unfavourable conditions, 
the chief of which is unwholesome stores. Any undue disturbance also makes the bees restless, such as frequent visits to the cellar, the use of white light in the cellar or jarring of any kind. If the bees are on wholesome stores and are brought into a suitable cellar before they have been exposed to much cold, a temperature ranging from 45 degrees $\mathrm{F}$. to 50 degrees $\mathrm{F}$. will give satisfactory results even during the longest winter.

In taking temperature of the bee-cellar, it is very necessary to use reliable thermometers. Cheap thermometers may be quite accurate at 30 degrees $\mathrm{F}$.,

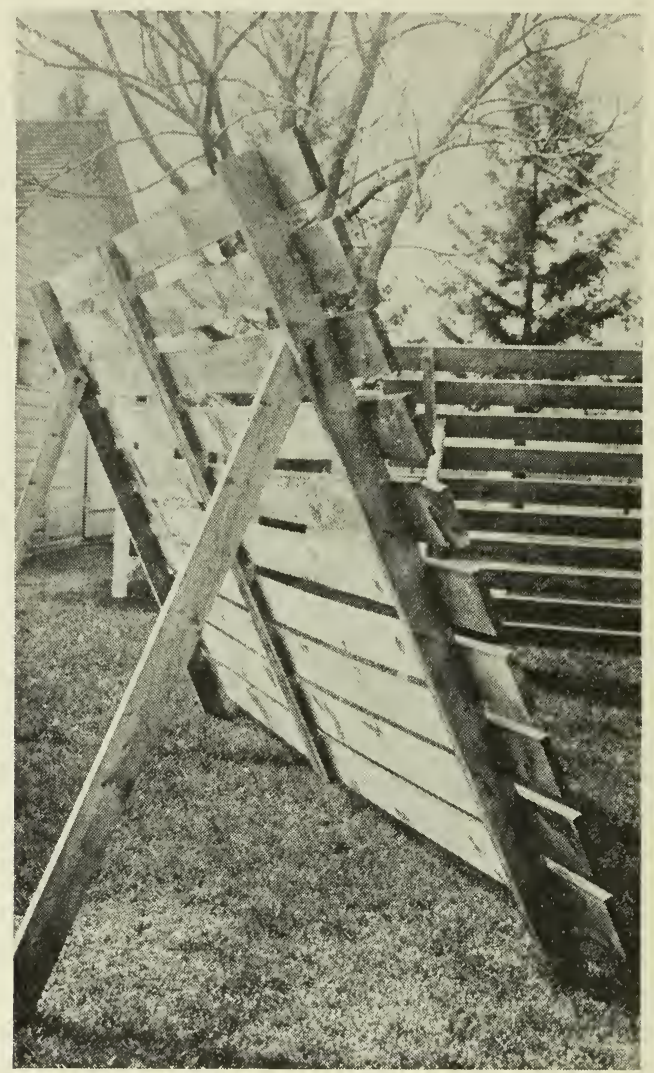

FIG. 7.-Section of portable wind-break, Twelve feet long, 7 feet high. Slats are 6 inches wide and spaced $2 \frac{1}{4}$ inches apart.

but may be several degrees in error between 45 and 50 degrees $\mathrm{F}$., which are the principal temperatures that we wish to record. It should also be remembered that the temperature near the ceiling may be several degrees higher than near the floor. At Ottawa, a thermograph (fig. 8) is used. This instrument records the temperature on charts for seven days at one winding. In addition to this, thermometers are hung at different levels.

If it is desired to measure the humidity of the bee-cellar, a wet- and drybulb thermometer can be used. If using the stationary kind, the air around the wet bulb must be fanned for at least one minute to get a fairly accurate reading. The percentage of relative humidity may then be calculated from tables based on the difference between the readings of the wet- and dry-bulb thermometers. The most accurate instrument is the sling psychrometer, or some- 
times called sling thermometer, which is whirled in the air for at least one minute before the readings are taken.

The entrances of the hives should be left open-wide open in cellars that can be kept at the right temperature-and the bees disturbed as little as possible. Mice should be kept out of the cellar, as they will do great harm to the bees and combs if allowed. The air of the cellar should be kept clean and sweet and for this purpose in a cellar crowded with colonies, the dead bees should be swept up and removed once or twice during the winter.

The usual practice is to bring the bees into the cellar as soon as possible after the last good cleansing flight the bees can be expected to have. In most places this is usually early in November. Unless the weather happens to be

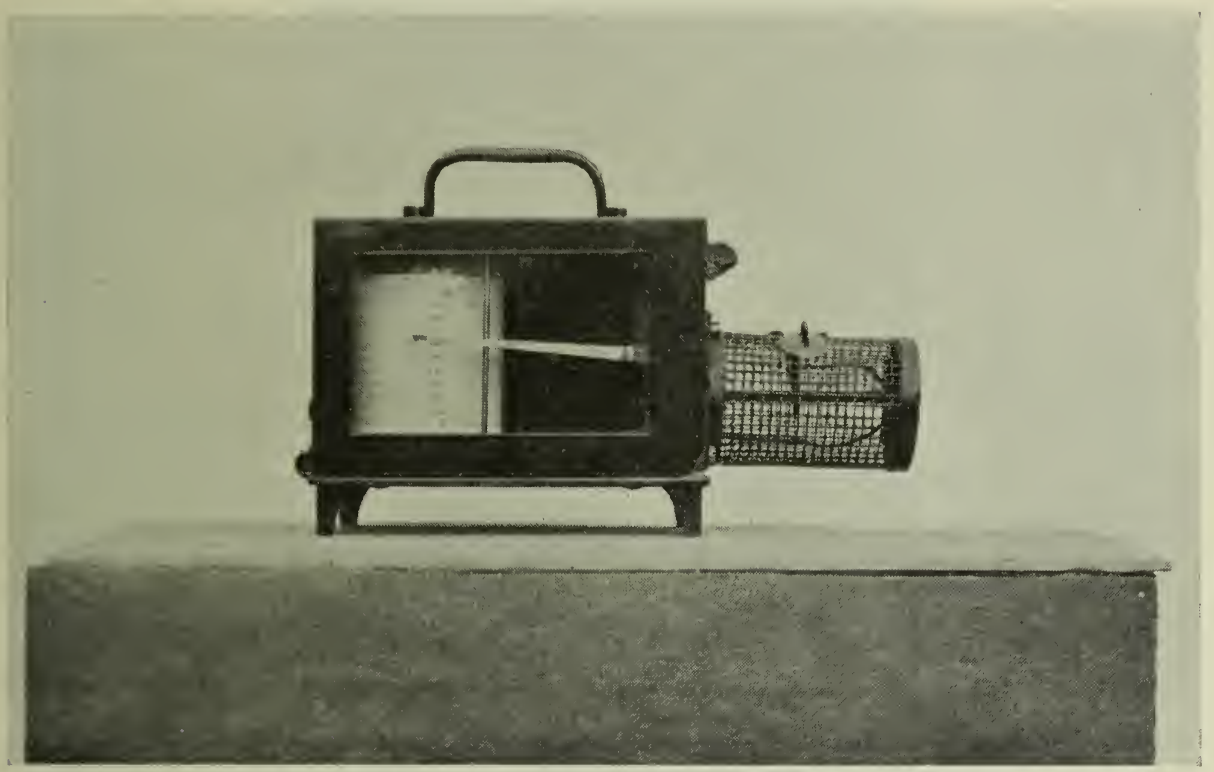

FIG. 8.-Thermograph. An instrument used for recording cellar temperatures at Ottawa.

open and warm, it is better to put the bees in directly after the first flight following November 1 . It is better to bring the bees in a little early than to leave them exposed to severe weather for several days waiting for a later flight which may not occur.

When carrying the bees into the cellar, do it with as little disturbance to the bees as possible. It is a good plan to first close the entrances with small pieces of sacking or paper and then to pick up the colonies gently and carry them in. Although the weather is usually too cool for bees to fly at this time, the closing of the entrances is advisable. In the cellar, the colonies should be placed on stands at least six inches from the floor and they can be tiered up two or three deep if necessary. The arrangement of the colonies in the cellar will depend upon space and the construction of the cellar. Usually, however, the colonies are placed in rows, back to back, so as to leave a passage between each double row. Some beekeepers prefer to leave the covers on the hives but, unless the cellar is very dry, it is better to remove them and in their places spread two or three thicknesses of sacking or similar material. Where honeyboards or quilts are used, these should be left on, as they usually provide enough openings to allow moisture to escape. As soon as all the colonies are in the cellar and the bees have quieted down, open the entrances. If the cellar is well 
constructed, the bees will require very little attention during the winter, except for an occasional visit to see that no moisture is condensing on the walls and to clean out the dead bees. It is only the poor cellars that need constant attention. Any cellar on the wall of which the moisture condenses is too cold. If the temperature cannot be raised, reduce the entrances of the hives and give more ventilation to carry off the moisture. A cold cellar causes higher consumption of stores which in turn will cause an accumulation of waste material in the intestines, and restlessness towards spring. Mouldy combs in the spring indicate that the cellar was too cold, as a cellar kept at the right temperature is too dry for moulds to develop.

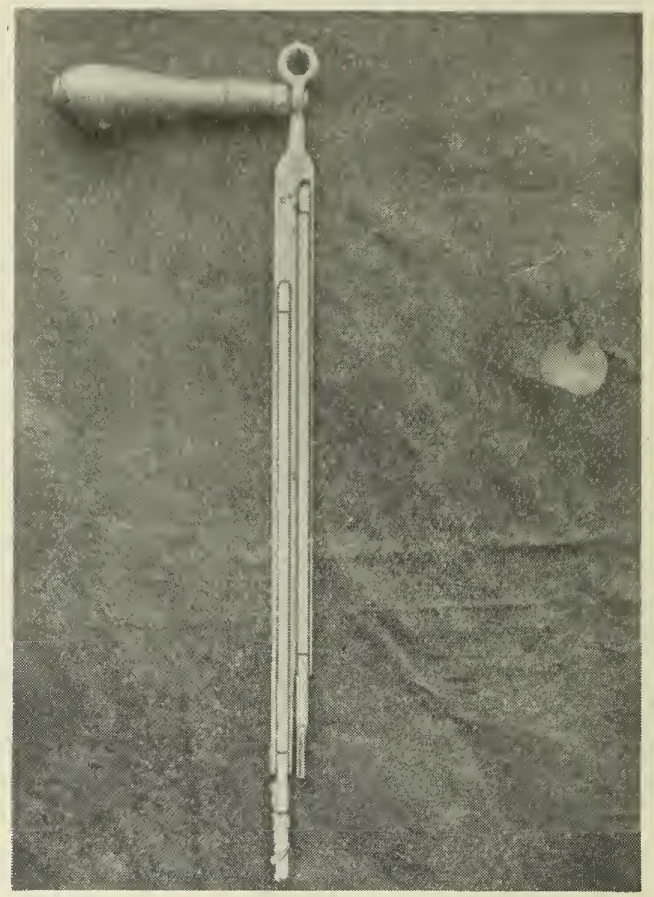

FIG. 9.-Sling psychrometer, for measuring humidity of air.

\section{WINTERING OUTSIDE}

In wintering outside, it is of utmost importance that the apiary be well protected from wind. A good wind-break around the apiary is of as much importance as good cases and packing. Therefore, if the apiary is not well protected from cold winds by a natural windbreak, such as rising ground or groves of trees or bushes, one should be provided. A good, thick hedge of evergreens or some thick-growing bushes, such as caragana, planted around the apiary, offers good protection. Failing this, a slatted board fence about seven or eight feet high is the next best thing. A tight board fence is not satisfactory, as it is likely to cause whirls. If the apiary is not permanently located, tl:e board fence is best if made in sections, (as shown in figs. 6 and 7) which makes it portable and very easy to move at any time, and also allows it to be stored away for the summer months, if necessary. Buildings cannot always be relied upon to serve as wind-breaks, as they often cause eddies which may strike certain colonies in the yard and do as much damage as a straight wind. Windbreaks are not only necessary during the fall, winter and spring, but they are also of benefit during the summer, especially in localities exposed to high winds, such as the open prairies. 
The cases in which bees are packed may be made to hold one or more colonies according to the tastes of the beekeeper, but the must be large enough to hold sufficient packing on bottom, sides and top in addition to the colonies that are to be placed in them. Some bee keepers use a long case holding several colonies side by side and all facing in one direction. The main disadvantage of such a case is that when the bees are unpacked in the spring and the colonies separated the bees that have already been flying and marked their location are apt to drift to other colonies, so that the colonies that are moved to a new location lose many of their flying bees. This, of course, can be overcome to a certain extent by moving the colonies gradually, a short distance each day, but this requires a great deal of time and labour.

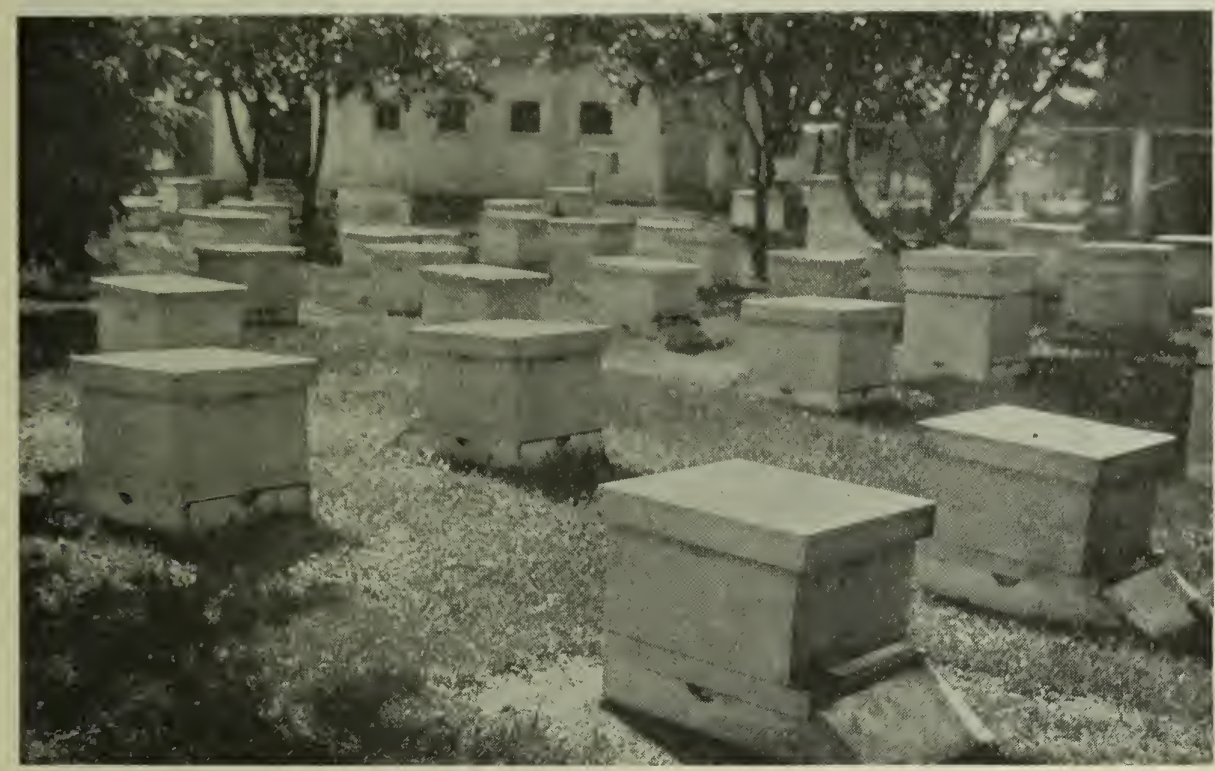

FIG. 10.-Colonies standing in groups of four. This grouping making less work when packing in the fall. The case is placed in the centre of each group.

Double- and single-colony cases are also used to a large extent and have proven quite satisfactory. Both kinds are used in the apiary at Ottawa and in many of the branch Farm apiaries. The double-colony case can he handled quite easily by one man and it also allows for the hives to face all in one direction, if so desired. The single-colony case has the advantage in that it can be left packed the whole year round, thus doing away with the labour of packing in the fall and unpacking in the spring, which is the main objection to outdoor wintering. This advantage, however, is nullified should the packing in these cases become wet during the summer: it will have to ke changed, because wet packing loses its insulating value. Single cases are used quite extensively in southern Ontario and almost entirely in British Columbia. The chief objection to both double and single cases is the cost.

In some localities a few beekeepers are using a double-walled, permanentlypacked hive, but for the greater part of Canada such hives do not offer enough protection, unless built of such size as to make them clumsy for handling. They are also objectionable should it become necessary to move the apiary at any time. The cost of protecting an apiary in double-walled hives is also very high.

The most economical case is one that is made to take four hives en bloc. Such a case uses less material per colony than cases made to take one, two or 
more hives side by side, as each colony is protected on two sides by its neighbours. Cases of this type, but of varying construction, have been used in the apiaries of the Experimental Farms system for many years with great success. and it is cases of this type that are in general use throughout Canada.

In addition to being large enough to hold sufficient packing, the packing case should be made tight, so as to keep the packing dry; therefore, it is best to use matched lumber for building the cases. The covers should be protected with some waterproof roofing material. The case must also be provided with flight-holes opposite to each colony, and these should be made so that they can be reduced in size during extremely cold weather. It is also necessary to have a small hole about 1 inch in diameter at each end or side of the case and

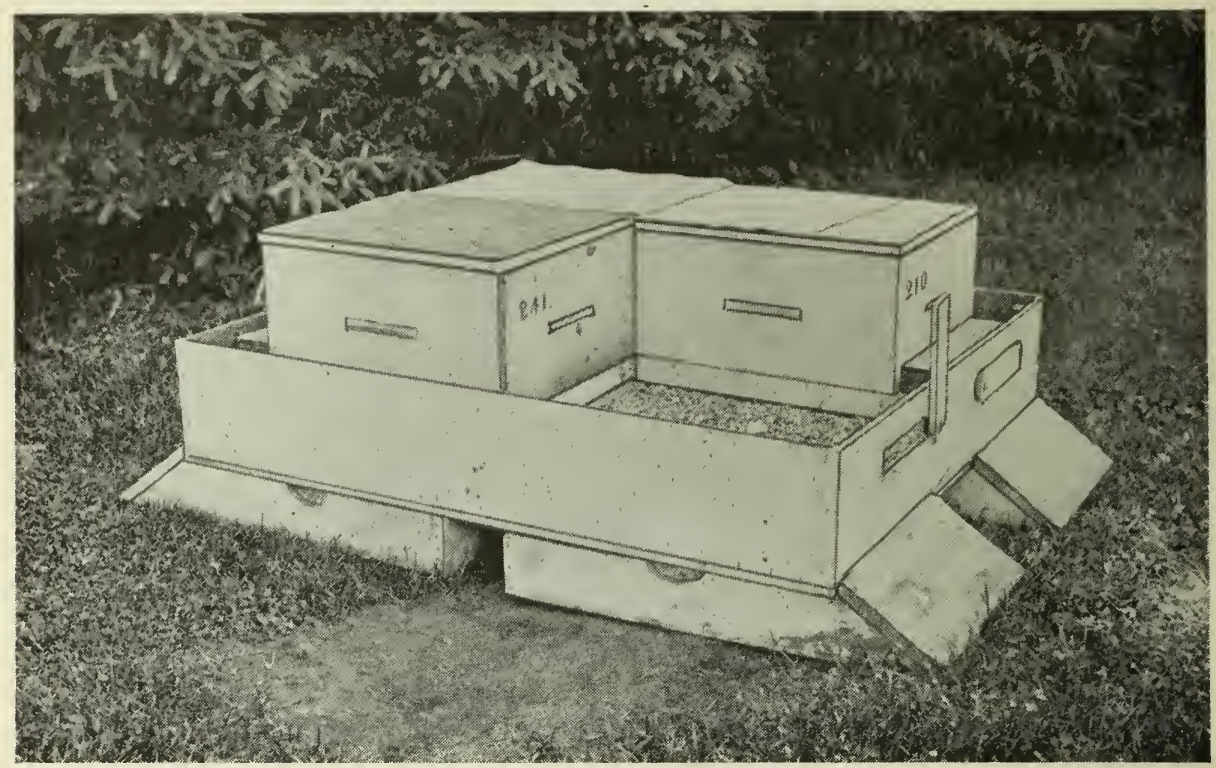

FIg. 11.-Colonies placed in tray of case with bridges in place and bottom packing in,

near the top so that there is a free circulation of air above the top packing. It is advisable to make cases collapsible, as this makes the packing and unpacking of colonies easier, and the cases may be stored in the flat during the summer months. When assembled, the ends and sides may be held together by hooks, or they may be held fastened more firmly by means of a thumb-screw near the top in combination with the dowels or pegs in the floor to prevent spreading below.

The construction of the flight-holes in the case needs particular attention. They should be cut in the ends of the cases opposite the entrance of the hives and should be as far apart as possible. Each entrance should be from four to eight inches long by one inch high and have a close-fitting piece of wood revolving on a screw which will reduce it to three-eighths of an inch long by one inch high. There should be no projecting ledge beneath the entrance on which the snow and ice might lodge. A small nail or screw driven in just below the entrance for the revolving block to rest on when the entrance is closed is quite satisfactory.

A tunnel through the packing connects the entrance of the hive with the flight-holes in the case. The standard floor-board projects in front of the hive about $2 \frac{1}{2}$ inches. When the colony is put in the case and the floor-board of the hive butts up close to the case there is space only for $2 \frac{1}{2}$ inches of packing; 
therefore, to get at least 4 inches of packing in front of the hives, blocks of wood $1 \frac{3}{8}$ inches thick will have to be nailed on the inside of the case just below the entrances, or special bridges will have to be constructed. The bridges are the most convenient. The bridge should be made so as to provide a tunnel from the hive to the case wall for approximately the full width of the hive entrance and at least $\frac{5}{8}$ of an inch deep. Experiments, however, show that a deeper tunnel is more satisfactory, as it provides a better circulation of air. A bridge that provides a tunnel $1 \frac{1}{2}$ inches deep (as shown in Plate II) is recommended.

The packing material used should be of small size, so as to supply numerous dead-air spaces. Planer shavings, forest leaves that have been kept at least one year, and chaff have proven very satisfactory. Sarwdust is also used by some,

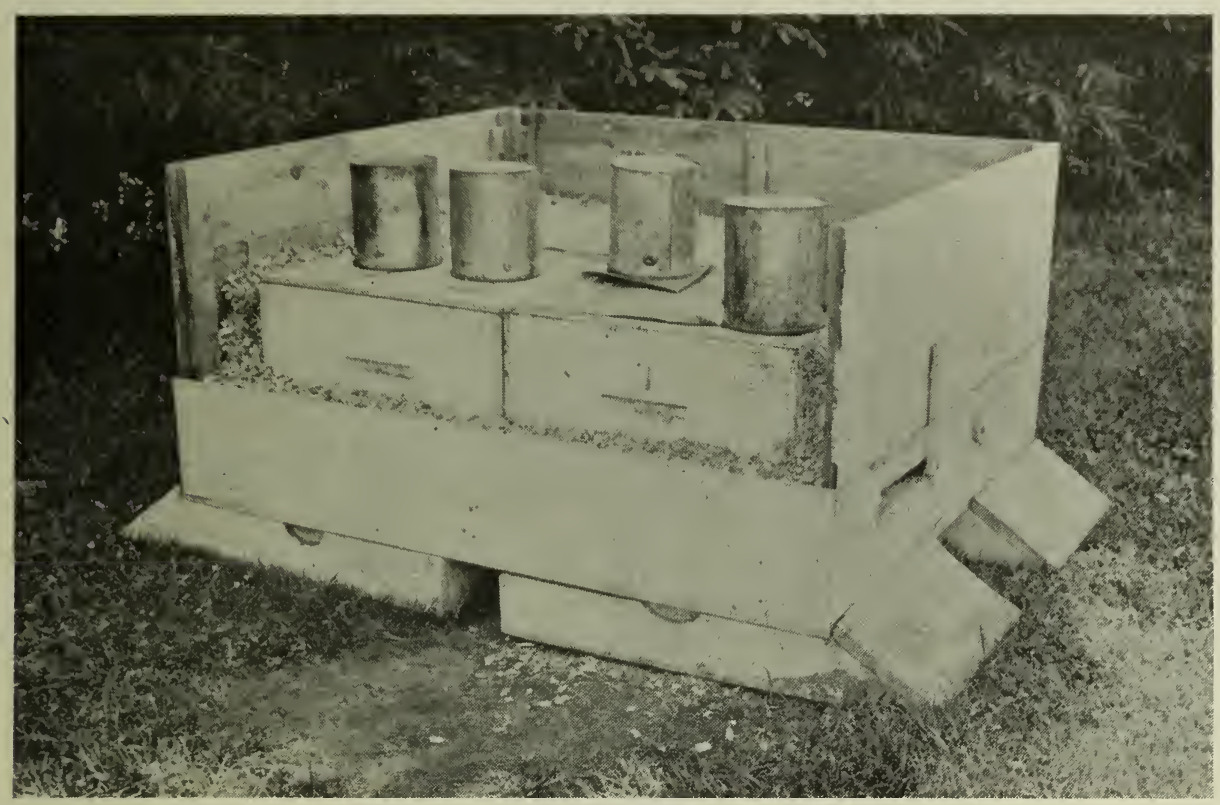

Fig. 12.-Colonies in case with bottom and side packing and feeders in place.

but this material is inclined to absorb moisture very readily and does not appear to be as good for insulation as the other materials mentioned. Buckwheat hulls and moss, where obtainable, are also suitable. The amount of packing used should be at least 3 inches on the bottom, 4 inches on all four sides, and 6 to 8 inches on top. In very cold regions where the temperature drops to 30 or 40 degrees below zero and remains so for several days at a time, thicker packing should be used, especially if the apiary is not well protected from winds. So far, extra thick packing has not been found particularly advantageous at Ottawa, even when the temperatures have dropped to more than 20 degrees below zero.

To receive full benefit from protection in the fall, the bees should be packed not later than the last week in September, preferably before the fall feeding is done. To avoid loss of bees, the colonies, if standing in rows, should be gradually brought together during late summer, so as to occupy nearly the same position and face in the same direction as they will in the cases. When wintering outside, it is advisable to have the colonies standing all summer in groups of two or four, according to the size of case used, so as to avoid the extra labour of moving them into position.

When ready to pack, first place the stand in position and on it the floor of the case so that the entrances of the cases will face east and west. With the 
aid of a spirit level true up the stand so that the case will stand level. Across the floor place three pieces of 2- by 3 -inch scantling, one near each end and one: in the centre. These are for the hives to rest on and to provide space for bottom packing. Between the scantlings, pour enough packing material to cover the floor and reach to the top of the scantling. Now remove the covers from the hives and place the colonies in position. The colonies should be as close together as it is possible to get them side by side and back to back, there should be no space between them for packing. The packing is then pushed in tightly below the floor-boards of the hives. Now assemble the sides and adjust the bridges and then fill up the sides with packing to the level of the top of the hives. The quilts or honey-boards should be left on the hives all winter to prevent the escape of too much heat. Where quilts are used, passages for the bees over the combs may be provided by placing small sticks beneath the quilts. As soon as the colonies are in the cases, the bees should be fed and as soon as feeding is done the top packing is given and the cases closed for the winter. It is better to give the top packing in the form of a cushion as it is much easier to handle. Satisfactory cushions may be made by filling bran bags three quarters full of material and then tying them near the mouth. Five or six of these partly filled bags can bc made to fit in over the top of the colonies perfectly. The entrances of the cases need not be closed down until cold weather is assured.

It is not necessary to remove the snow surrounding the cases during the winter because the bees will not smother even if buried deeply in it. In some places, however, where the snow lingers late in the spring, it is advisable to shovel the snow from the entrances towards the end of March. At this time all entrances should be cleared of dead bees. Later in the spring, as the weather becomes warmer and pollen is coming in freely, the revolving block should be raised to enlarge the entrances.

The bees should not be removed from their winter cases before they are working well in the first or second super, usually about the latter end of May or the beginning of June. The extra protection afforded during the spring by the packing, especially during the first few weeks of breeding, is one of the main advantages of outside wintering.

\section{CONSTRUCTION OF CASES}

If the packing case is made large enough and tight enough to keep the packing dry, it may be constructed to suit the individual tastes of the persons using it; but, as a guide to those who wish to build new cases, a few plans are here given. All the cases shown are in use at the various Experimental Farm apiaries.

The case shown in plate No. I consists of seven pieces: stand, floor, two sides, two ends and cover. It is made to hold either four Langstroth or four Jumbo hives with three inches of packing underneath and on the sides with eight to ten inches on top surmounted with a few inches of air space.

The stand is made of $\frac{7}{8}$-inch material with blocks in the corners and a central stringer on which the floor cleats bear. The use of a stand is advisable to raise the floor of the case from the ground so that the lower packing does not absorb moisture from the ground.

The floor is also made of $\frac{7}{8}$-inch material, with three cleats underneath. These cleats are $\frac{1}{2}$ inch shorter than the width of the floor, so as to allow $\frac{1}{4}$ of an inch of each side of the floor to rest on the stand. The cleats bear directly on the four corner posts and the central stringer of the stand. On the floor are placed 3 pieces (not shown) of 2 by 3 scantling, on which to set the hives and to provide for underneath packing. 


\section{-QuAdRUPLE CASE-}

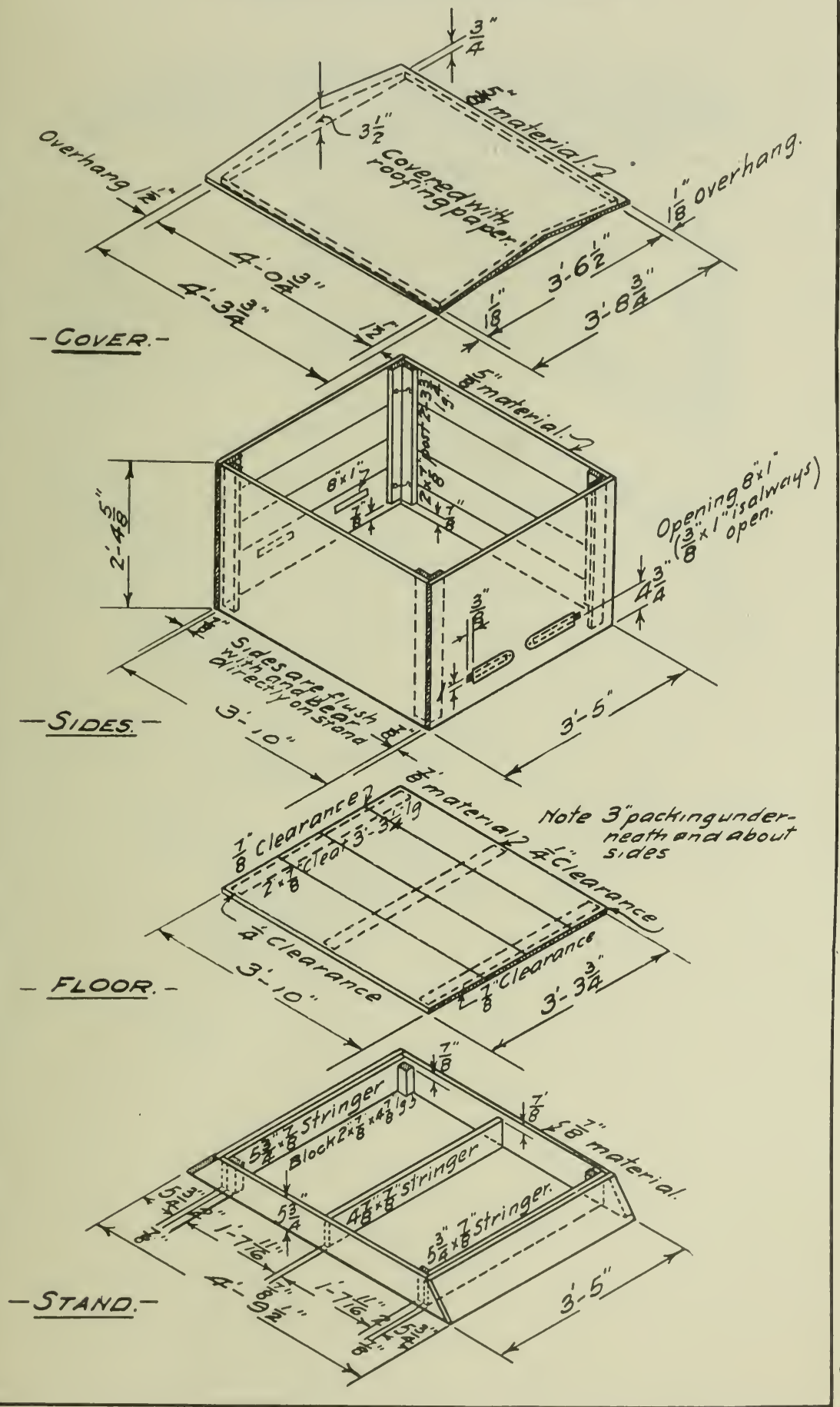




\section{QuAdruple CASE}

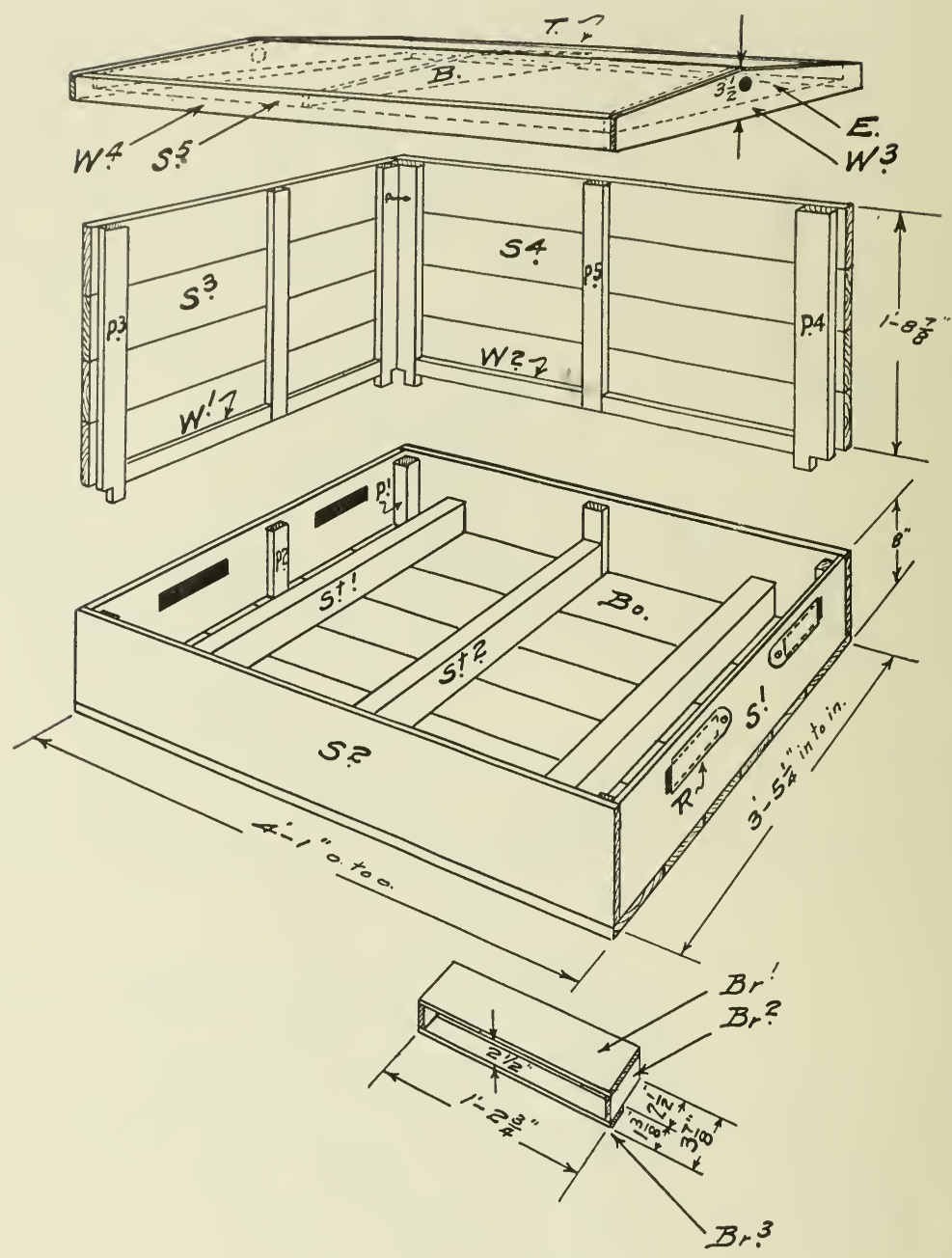

Plate II 


\section{Double Case}

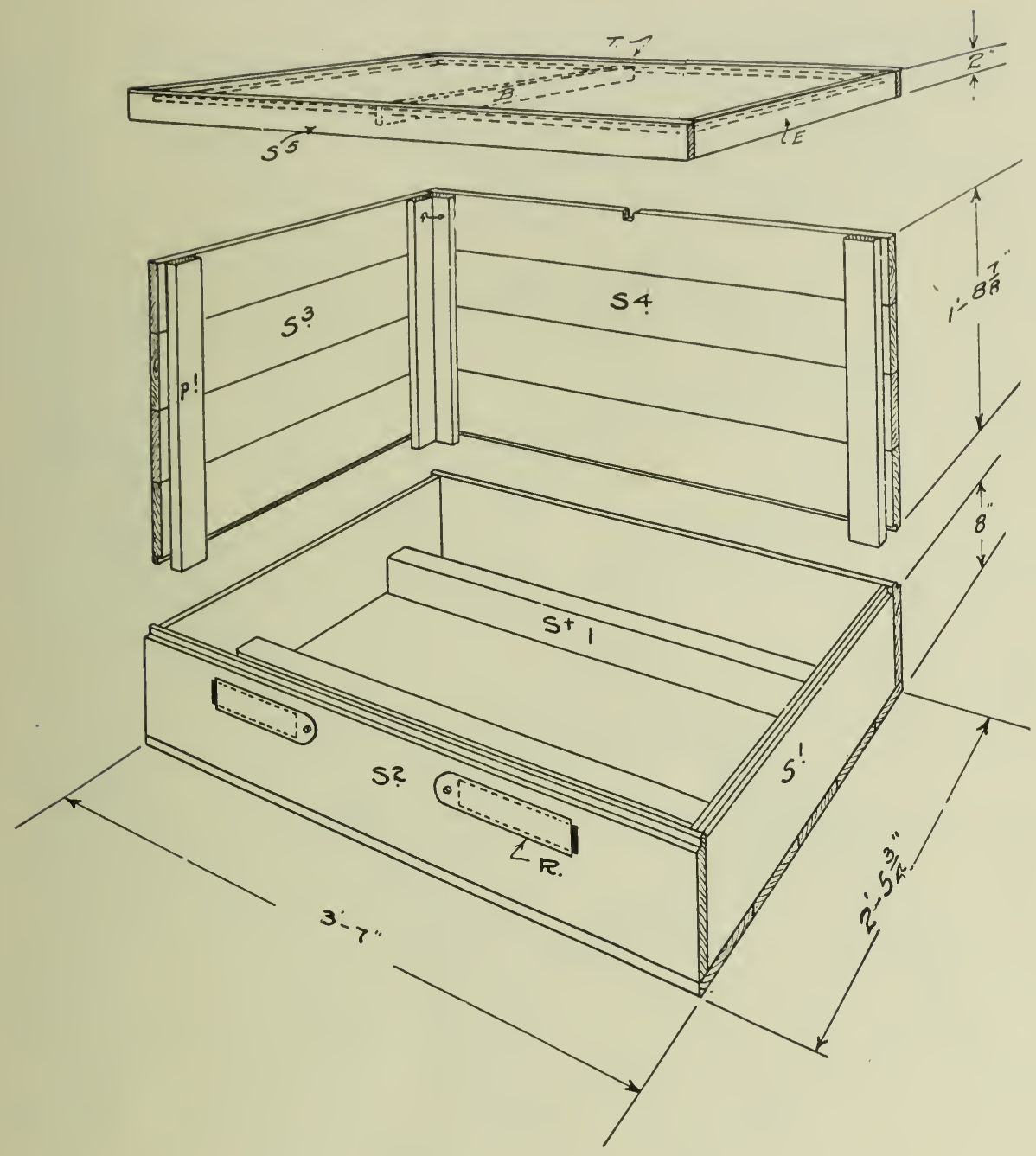

Plate III 


\section{KoOtenay Single CASE}

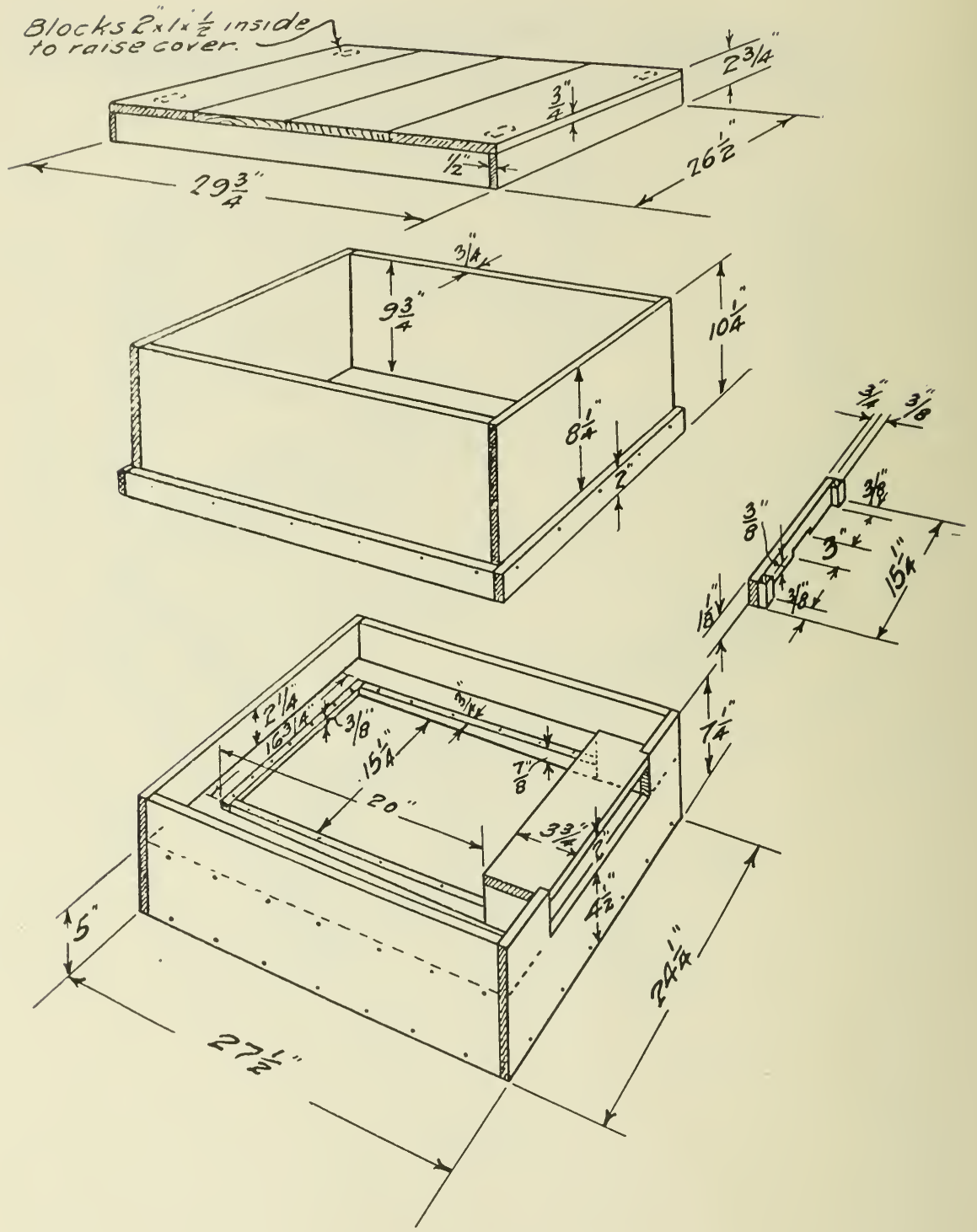

Plate IV 
The sides and ends are made of $\frac{5}{8}$-inch material, but $\frac{7}{8}$ of an inch may be used. They are fastened together at each corner by two hooks and eyes. When in place, the sides and ends bear directly on the stand, the outside being flush with the outsides of the stand. The corner cleats, however, are $\frac{7}{8}$ of an inch shorter than the depth of the sides and ends, and rest on the floor board. In each end are two flight holes, 8 inches long and 1 inch high, fitted with revolving blocks to reduce them to 1 inch by $\frac{3}{8}$ of an inch for the winter.

The bridges to provide a continuous passage from the hive entrance to the flight hole in the case are the same as shown in plate No. II, but narrower, the top of the bridge to be only $2 \frac{7}{8}$ inches wide instead of $3 \frac{7}{8}$ inches and the bottom strip $\frac{3}{8}$ of an inch wide instead of $1 \frac{3}{8}$ inches.

The cover is constructed of $\frac{5}{8}$-inch material and made to telescope over the sides and ends. Waterproof roofing is used on the top to shed water. There is an inch hole drilled through each end of the cover just beneath the overhang to allow for free circulation of air over the top packing.

The inside measurements of this case are 46 inches long, $39 \frac{3}{4}$ inches wide and $27 \frac{3}{4}$ inches deep. It is a simple case, easy to construct and handle, but should anyone decide to build from this plan it would be better to make the case two inches longer and wider to allow for 4 inches of packing instead of three.

Plate No. II shows another 4-colony case that is a decided improvement over that shown in plate No. I in that the colonies can be packed in it much faster and easier. In this case, parts of the sides and ends are attached to the floor making a tray 8 inches deep. The 2 by 3 -inch scantlings on which the colonies rest are permanently nailed in place and the flight holes are in the tray. When the colonies are ready to be packed, enough packing material is poured and pressed into the tray to fill it to the top of the scantlings. The colonies are then placed in position, and the bridges arranged before the sides are put on. The ends and sides are held together by means of one small hook and eye at each corner near the top, while the side cleats engage the tray at the bottom. A piece of weather-stripping is nailed on the inside along the lower edges of the sides and bottom to break the joint where sides and tray come together.

The cover is slightly gabled; telescopes over sides and ends; and is covered with prepared roofing to shed water. There is also an inch hole in each end gable for air.

The inside measurements of this case when assembled are 48 inches long, $41 \frac{1}{4}$ inches wide and 28 inches deep. It will take either four 10 -frame Jumbo or Langstroth hives and the latter may have a shallow food-chamber on them and still allow for six inches of top packing surmounted with an air-space. It also allows for 3 inches of packing underneath and 4 inches on all four sides.

No stand is shown in the drawing, but one should be used to raise the case from the ground. If a proper stand is not constructed a block or ordinary hive-stand under each corner may be used with satisfaction.

The material needed to build this case is as follows:-

$$
\text { For Tray }
$$

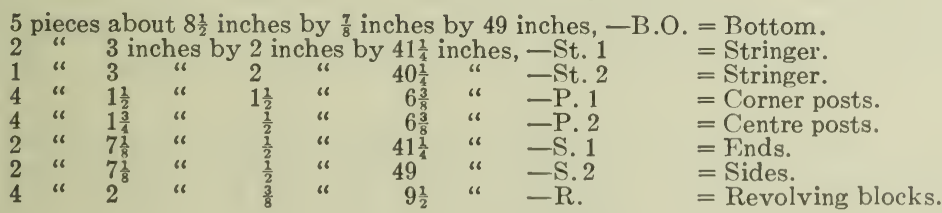

For Bridges

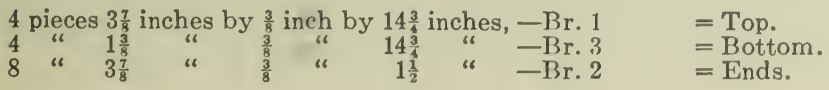


For Sides and Ends

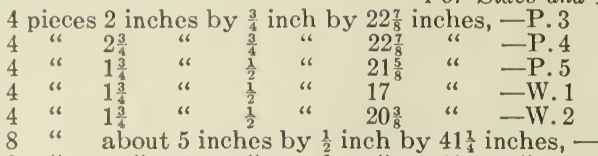

$$
\begin{aligned}
& =\text { Corner posts on ends. } \\
& =\text { Corner posts on sides. } \\
& =\text { Centre posts on sides and ends. } \\
& =\text { Weather-strip on ends. } \\
& =\text { Weather-strip on sides. } \\
& =\text { Matched lumber for ends. } \\
& =\text { Matched lumber for sides. }
\end{aligned}
$$

\section{For Cover}

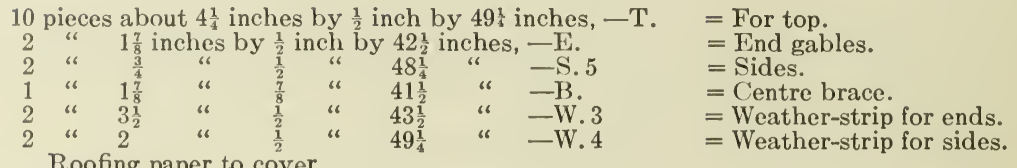

Roofing paper to cover.

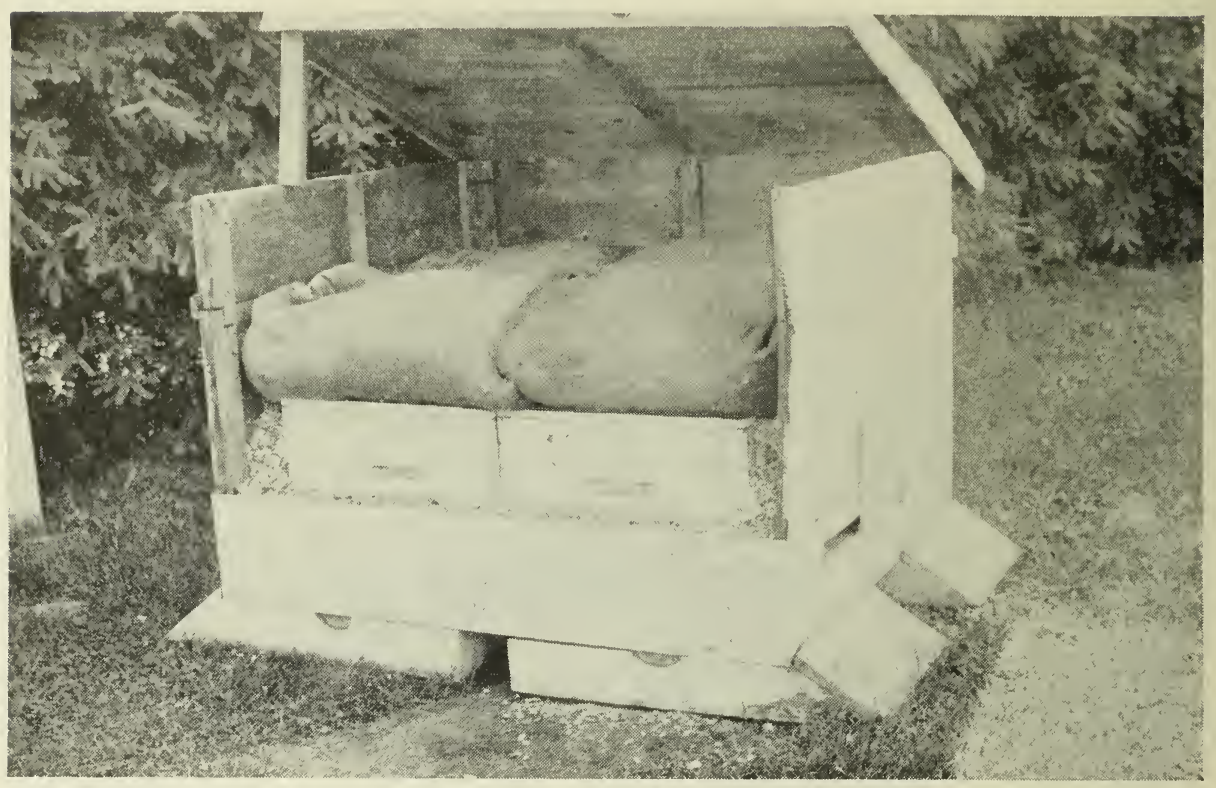

FIG. 13.-Top packing in bags. Case ready for closing for winter.

When making the cover, the roofing paper is put on before the weatherstripping. The edges of the paper are turned down over the edges of the cover and the weather-stripping nailed over them to hold in place.

Plate No. III shows a two-colony case made on the same plan as the quadruple case mentioned last. The material used in this case is $\frac{7}{8}$ of an inch thick. The upper edge of the tray and the lower edges of the sides and ends are halved, so that when the case is assembled the joint is broken without the aid of weather-stripping as in the four-colony case. The posts are 2 inches longer than the width of the sides or ends and fit into the tray to prevent spreading at the bottom.

Plate No. IV is the Kootenay single case as used in British Columbia. It is a splendid single-colony case. Although only one lift is shown between the floor-section and cover, t,wo are needed for the winter, when wintering in single brood-chambers. If wintering in double brood-chambers, three are necessary. The floor of this hive is sloping to the front but the bevelled cleats keep the hive itself level. The regular flcor-board is not used in this case. 


\section{OU'TDOOR VERSUS CELLAR WINTERING}

For a number of ycars experiments with both cellar and outdoor wintering have been conducted at Ottawa. These experiments have shown that bees wintered outside in packing-cases start breeding earlier in the spring and average stronger by the end of May. They have also shown that no greater losses occur outside than inside, provided the bees receive the proper care in the fall. The factors for successful wintering have already been discussed.

At Ottawa all colonies are examined for strength during the latter part of September. Any colonies that have less than six combs covered by bees are brought together two into one hive with a tight-fitting division-board between them. During the last week in September the colonies, without the

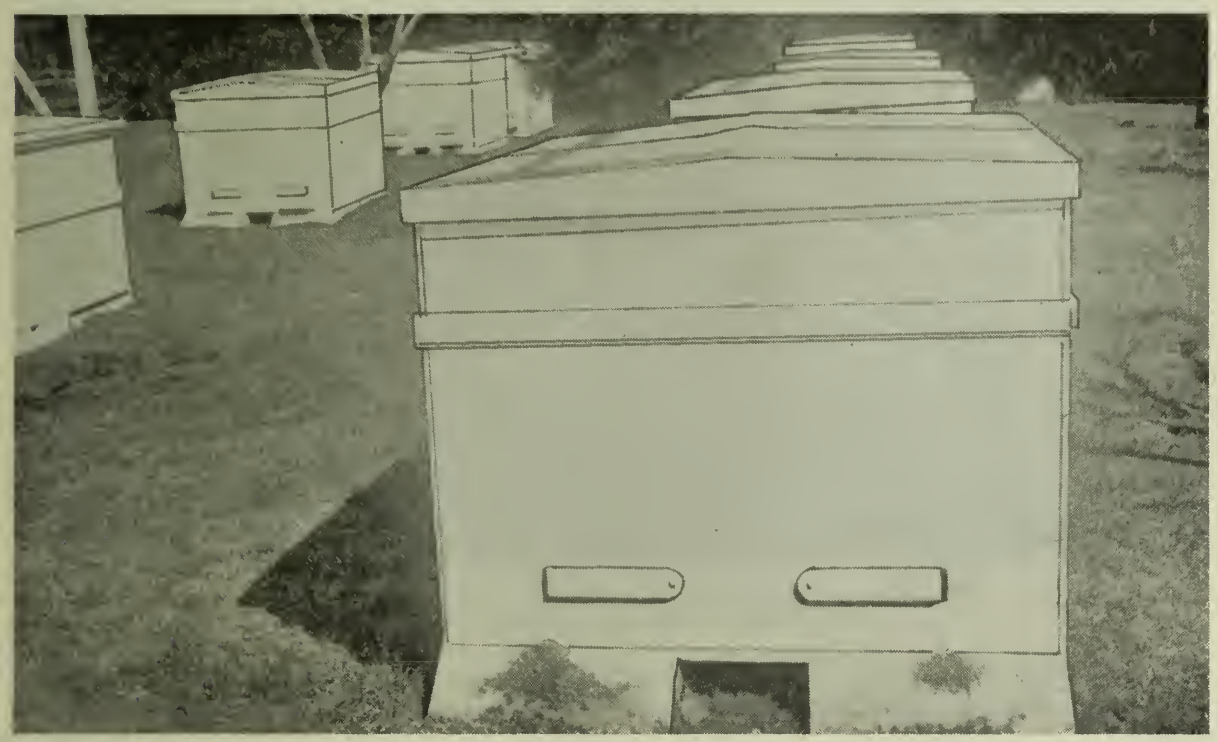

Fic. 14.-Good wintering, Bees fed an abundance of sugar syrup in fall. Note the small number of dead bees at the entrance.

covers, are all weighed to determine the amount of food they require to furnish enough stores for the winter. Immediately after weighing, the outdoor-wintered colonies are placed in their cases with bottom and side packing only. Feeding is usually commenced about the first of October. The outside-wintering colonies that are to be wintered on honey alone are given a super containing enough honey to bring the weight of the colony, without its cover, up to at least 75 pounds. For cellar wintering, enough sugar syrup is given to bring the weight of the colony up to at least 65 pounds. No colony starts the winter weighing less than these amounts. In fact, the majority of the colonies are well above the figures given. Those colonies that are to have their stores supplemented with syrup are given sugar syrup (2 parts of sugar to one part of water) in 10-pound honey-pail feeders as rapidly as the bees will take it until they have sufficient for the winter. The feeding is usually finished by the end of the first week in October. As soon as the outdoor-wintered bees are fed, the top packing is given and the cases closed for the winter. Planer shavings are used for packing material. The colonies that are to be wintered in the cellar are left outside until just after the last good flight that the bees may take late 
in October or early in November-usually during the first week in November. The bee-cellar is beneath the office building, and well below the surface of the ground. The floor and walls are of cement and it is well insulated against outside temperature. It is also supplied with a good ventilating system that can be controlled at will. The temperature of the cellar is kept as close to 48 degrees F. as possible through the winter, as it is found that the bees are

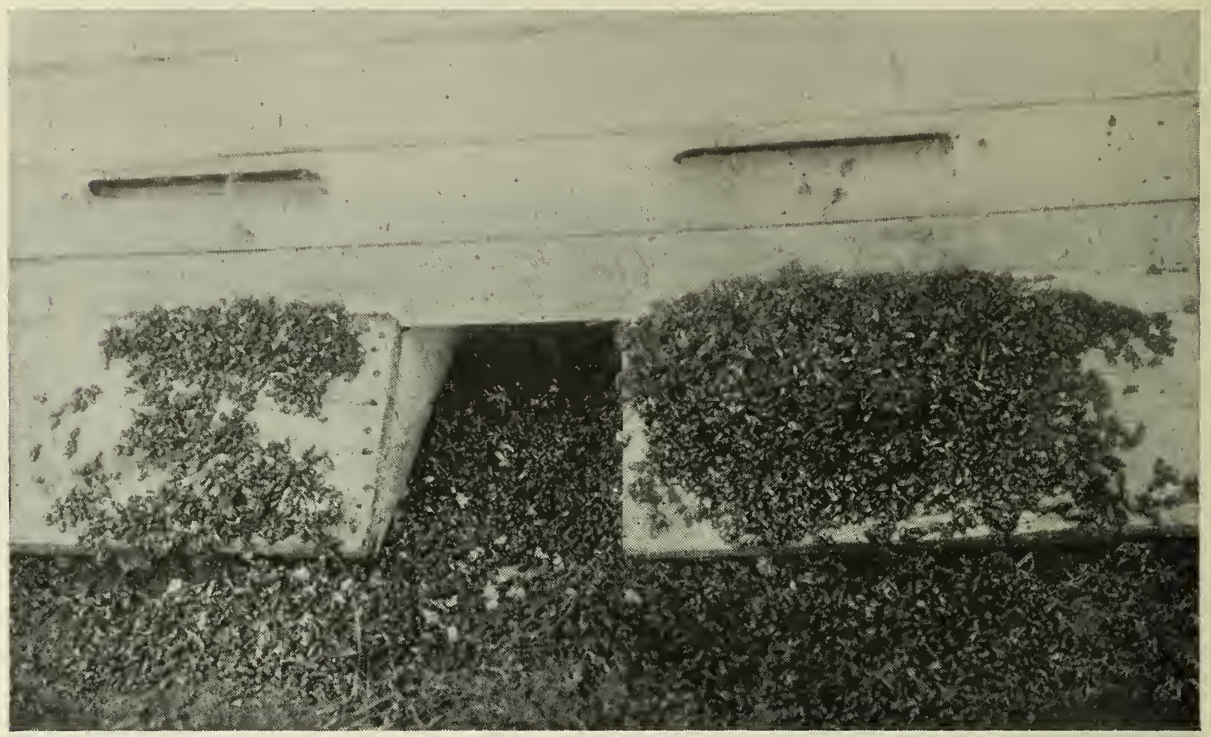

FIG. 15.-Colony to the right was wintered on fall honey and had a heavy mortality. Note the large number of dead bees at the entrance.

quieter at this temperature. The entrances of the hives are left wide open, the hive-covers are removed, but the oiled quilts are left on and one or two bags spread over them. Although the bees winter well in this cellar, on the whole, the outdoor-wintered bees appear to have the advantage.

The following table shows the comparative results of colonies wintered in the cellar and in packing-cases out-of-doors:-

COMPARISON BETWEEN COLONIES WINTERED IN CELLAR AND OUT-OF-DOORS

\begin{tabular}{|c|c|c|c|c|c|c|c|c|c|c|}
\hline \multirow[t]{2}{*}{ Year } & \multicolumn{2}{|c|}{$\begin{array}{l}\text { Approximate } \\
\text { number of combs } \\
\text { covered by } \\
\text { bees in the fall } \\
\text { at last } \\
\text { examination }\end{array}$} & \multicolumn{2}{|c|}{$\begin{array}{c}\text { Number of } \\
\text { colonies } \\
\text { placed in winter } \\
\text { quarters }\end{array}$} & \multicolumn{2}{|c|}{$\begin{array}{l}\text { Number of } \\
\text { colonies that died }\end{array}$} & \multicolumn{2}{|c|}{$\begin{array}{l}\text { Number that } \\
\text { had to be united }\end{array}$} & \multicolumn{2}{|c|}{$\begin{array}{l}\text { Approximate } \\
\text { number of combs } \\
\text { covered by } \\
\text { bees in the spring } \\
\text { at first } \\
\text { examination }\end{array}$} \\
\hline & Cellar & Outside & Cellar & Outside & Cellar & Outside & Cellar & Outside & Cellar & Outside \\
\hline $\begin{array}{l}1921-22 \ldots \\
1922-23 \ldots \\
1923-24 \ldots \\
1924-25 \ldots \\
1925-26 \ldots\end{array}$ & $\begin{array}{l}7 \cdot 4 \\
7 \cdot 9 \\
9 \cdot 0 \\
8 \cdot 9\end{array}$ & $\begin{array}{l}8 \cdot 0 \\
8 \cdot 0 \\
9 \cdot 6 \\
9 \cdot 0\end{array}$ & $\begin{array}{l}34 \\
50 \\
48 \\
14 \\
15\end{array}$ & $\begin{array}{l}21 \\
28 \\
36 \\
77 \\
72\end{array}$ & $\begin{array}{l}1 \\
4 \\
5 \\
0 \\
0\end{array}$ & $\begin{array}{l}0 \\
0 \\
1 \\
0 \\
1\end{array}$ & $\begin{array}{l}1 \\
4 \\
3 \\
0 \\
0\end{array}$ & $\begin{array}{l}1 \\
0 \\
2 \\
2 \\
0\end{array}$ & $\begin{array}{l}5 \cdot 3 \\
5 \cdot 4 \\
5 \cdot 1 \\
5 \cdot 7 \\
5 \cdot 5\end{array}$ & $\begin{array}{l}6 \cdot 3 \\
6 \cdot 9 \\
6 \cdot 6 \\
6 \cdot 7 \\
7 \cdot 3\end{array}$ \\
\hline
\end{tabular}


The results, as given in the table, show that for the period of five years the greatest losses occurred amongst the cellar-wintered bees. It also shows that the average strength of the colonies wintered outside is higher both in fall and spring. It has also been found that these colonies breed up much faster during the spring and early summer, due to the extra protection they get by being left in their cases until late May or early June.

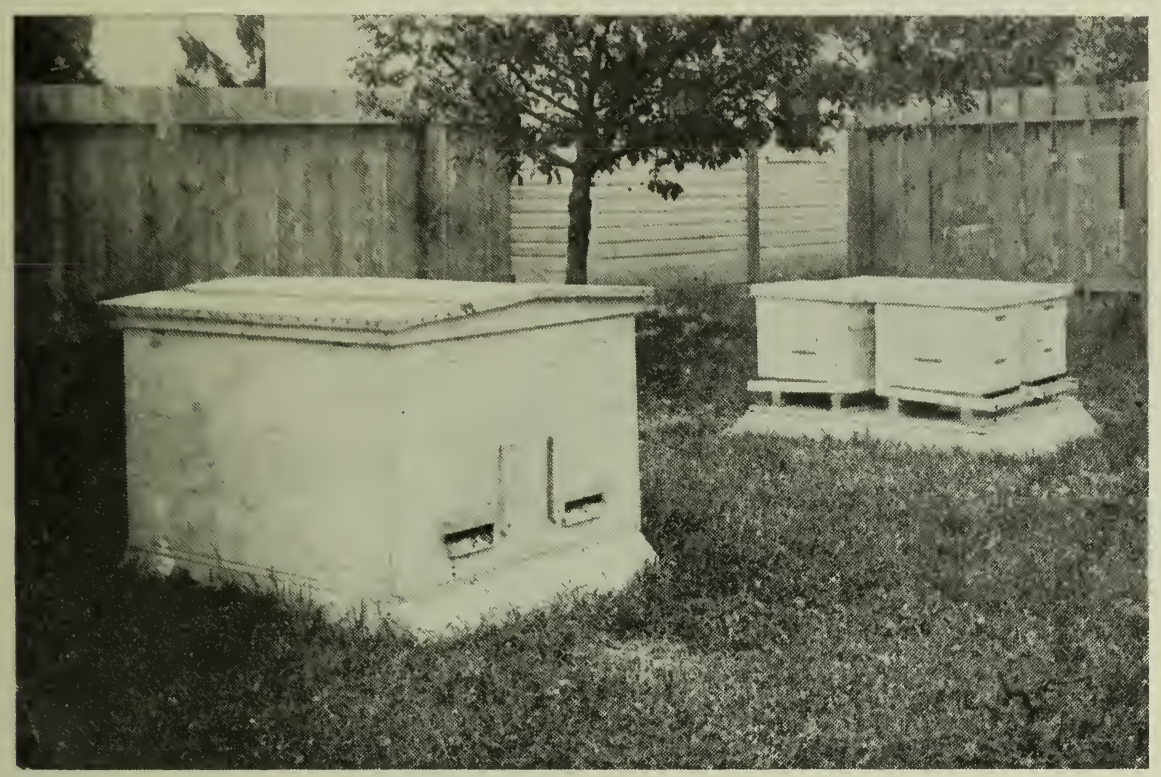

Fig. 16.-Colonies packed in case shown on plate I.

A comparison of the two groups of colonies regarding honey production is also in favour of the outdoor-wintered colonies, as shown in the following table:-

HONEY PRODUCED BY CELLAR-WINTERED AND OUTDOOR-WINTERED COLONIES

\begin{tabular}{|c|c|c|c|c|c|c|c|c|}
\hline \multirow{3}{*}{ Year } & \multirow{2}{*}{\multicolumn{2}{|c|}{ Number of colonies }} & \multicolumn{4}{|c|}{ Average crop per colony } & \multirow{2}{*}{\multicolumn{2}{|c|}{$\begin{array}{l}\text { Difference in } \\
\text { favour of } \\
\text { outdoor- } \\
\text { wintered } \\
\text { colonies }\end{array}$}} \\
\hline & & & \multicolumn{2}{|c|}{$\begin{array}{c}\text { Cellar- } \\
\text { wintered }\end{array}$} & \multicolumn{2}{|c|}{$\begin{array}{l}\text { Outdoor- } \\
\text { wintered }\end{array}$} & & \\
\hline & Cellar & Outdoors & Lb. $\mathrm{O}$ & $\mathrm{Oz}$ & Lb. & $\mathrm{Oz}$. & Lb. & $\mathrm{Oz}$ \\
\hline $\begin{array}{l}1922 . \\
1923 . \\
1924 . \\
1925 .\end{array}$ & $\begin{array}{r}20 \\
18 \\
30 \\
8\end{array}$ & $\begin{array}{l}15 \\
20 \\
18 \\
52\end{array}$ & $\begin{array}{rr}57 & \\
135 & 1 \\
79 & \\
103 & 1\end{array}$ & $\begin{array}{r}5 \\
11 \\
7 \\
14\end{array}$ & $\begin{array}{r}81 \\
179 \\
94 \\
120\end{array}$ & $\begin{array}{r}5 \\
9 \\
4 \\
13\end{array}$ & $\begin{array}{l}24 \\
43 \\
14 \\
16\end{array}$ & $\begin{array}{r}0 \\
14 \\
13 \\
15\end{array}$ \\
\hline
\end{tabular}

A number of the colonies wintered both in the cellar and in cases were used for other experimental work, hence, are not given in the preceding table. 
Bees have been wintered outside very successfully for a number of years at the following Experimental branch Farms:-

\section{Farm}

Type of case used

Charlottetown, P.E.I....................... 4-colony cases.

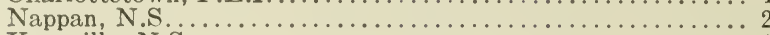

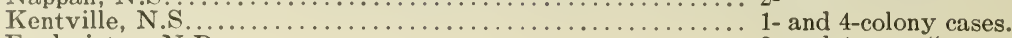

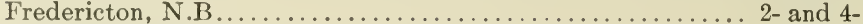

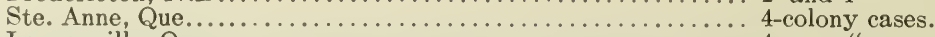

Lennoxville, Que................................ 4-

Kapuskasing, Ont......................

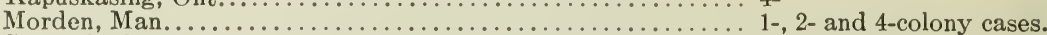

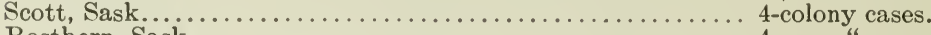

Rosthern, Sask........................

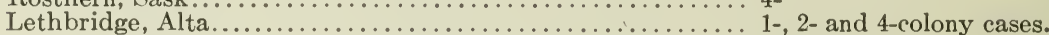

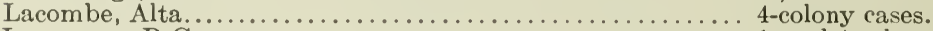

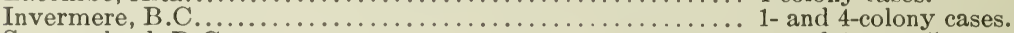

Summerland, B.C...........................

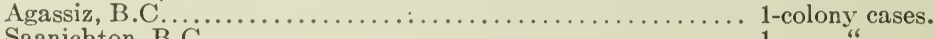

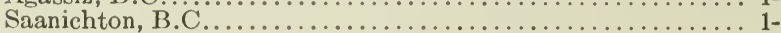

At some of these locations, the winter weather is very severe, the temperature often remaining below zero for several days at a time and sometimes dropping more than 40 degrees below zero; and yet the bees winter well. The following table gives the mean, highest and lowest temperatures for the past four years at Ottawa; also the number of days of zero weather for each month during which the bees were confined to their winter quarters:-

TABLE OF TEMPERATURES

\begin{tabular}{|c|c|c|c|c|c|c|}
\hline \multirow{2}{*}{ Month } & \multicolumn{3}{|c|}{$1922-23$} & \multicolumn{3}{|c|}{$1923-24$} \\
\hline & Mean & Highest & Lowest & Nean & Highest & Lowest \\
\hline \multirow[t]{3}{*}{ 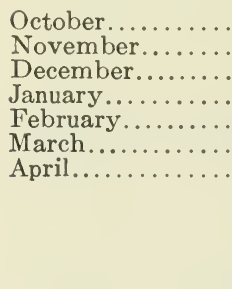 } & $\begin{array}{r}44 \cdot 5 \\
34 \cdot 6 \\
17 \cdot 2 \\
8 \cdot 8 \\
7 \cdot 8 \\
18 \cdot 0 \\
38 \cdot 2\end{array}$ & $\begin{array}{l}82 \cdot 0 \\
55 \cdot 0 \\
54 \cdot 0 \\
38 \cdot 0 \\
34 \cdot 0 \\
44 \cdot 0 \\
81 \cdot 0\end{array}$ & $\begin{array}{r}16 \cdot 0 \\
16 \cdot 0 \\
-12 \cdot 0 \\
-17 \cdot 0 \\
-33 \cdot 0 \\
-13 \cdot 0 \\
-5 \cdot 0\end{array}$ & $\begin{array}{r}46 \cdot 1 \\
34 \cdot 9 \\
28 \cdot 6 \\
12 \cdot 3 \\
8 \cdot 9 \\
29 \cdot 0 \\
40 \cdot 8\end{array}$ & $\begin{array}{l}71 \cdot 0 \\
53 \cdot 0 \\
50 \cdot 0 \\
41 \cdot 0 \\
30 \cdot 0 \\
50 \cdot 4 \\
74 \cdot 0\end{array}$ & $\begin{array}{r}22 \cdot 0 \\
19 \cdot 0 \\
-5 \cdot 0 \\
-29 \cdot 8 \\
-12 \cdot 4 \\
3 \cdot 0 \\
13 \cdot 0\end{array}$ \\
\hline & \multicolumn{3}{|c|}{$1924-25$} & \multicolumn{3}{|c|}{$1925-26$} \\
\hline & Mean & Highest & Lowest & Mean & Highest & Lowest \\
\hline $\begin{array}{l}\text { October......... } \\
\text { November...... } \\
\text { December...... } \\
\text { January ........ } \\
\text { February ........ } \\
\text { March........... } \\
\text { April............ }\end{array}$ & $\begin{array}{r}47 \cdot 8 \\
35 \cdot 8 \\
14 \cdot 9 \\
5 \cdot 5 \\
20 \cdot 9 \\
29 \cdot 9 \\
43 \cdot 5\end{array}$ & $\begin{array}{l}75 \cdot 0 \\
65 \cdot 0 \\
47 \cdot 0 \\
37 \cdot 0 \\
43 \cdot 0 \\
58 \cdot 0 \\
78 \cdot 0\end{array}$ & $\begin{array}{r}27 \cdot 0 \\
7 \cdot 0 \\
-22 \cdot 0 \\
-36 \cdot 0 \\
-11 \cdot 0 \\
-13 \cdot 0 \\
20 \cdot 0\end{array}$ & $\begin{array}{l}38 \cdot 9 \\
32 \cdot 0 \\
18 \cdot 4 \\
13 \cdot 4 \\
11 \cdot 7 \\
18 \cdot 9 \\
33 \cdot 2\end{array}$ & $\begin{array}{l}61 \cdot 0 \\
55 \cdot 0 \\
43 \cdot 0 \\
39 \cdot 0 \\
37 \cdot 0 \\
47 \cdot 0 \\
65 \cdot 0\end{array}$ & $\begin{array}{r}11 \cdot 0 \\
-11 \cdot 0 \\
-20 \cdot 0 \\
-24 \cdot 0 \\
-24 \cdot 0 \\
-19 \cdot 0 \\
7 \cdot 0\end{array}$ \\
\hline
\end{tabular}

Number of Days with Temperature below Zero

\begin{tabular}{|c|c|c|c|c|}
\hline Month & $1922-23$ & $1923-24$ & $1924-25$ & $1925-26$ \\
\hline 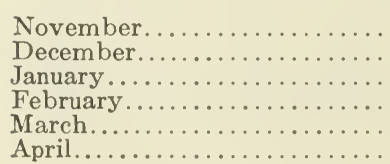 & $\begin{array}{r}0 \\
6 \\
18 \\
14 \\
6 \\
1\end{array}$ & $\begin{array}{r}0 \\
1 \\
14 \\
19 \\
0 \\
0\end{array}$ & $\begin{array}{r}0 \\
10 \\
19 \\
6 \\
3 \\
0\end{array}$ & $\begin{array}{r}2 \\
6 \\
14 \\
13 \\
7 \\
0\end{array}$ \\
\hline
\end{tabular}




\section{SPRING MANAGEMENT}

It has been said that cellar-wintered colonies should not be moved from the cellar before pollen and nectar are available in the spring. A good index of the right time is when the first willows show yellow pollen; or, if one has an opportunity of watching, when outdoor-wintered bees start bringing in new supplies. In many places, it is an advantage to give the colonies that have been brought out of the cellar some protection, but at Ottawa where the spring warms up quickly in the average season, this has not been found worth while. Shelter from cold winds, however, is necessary and packed hive-covers are desirable.

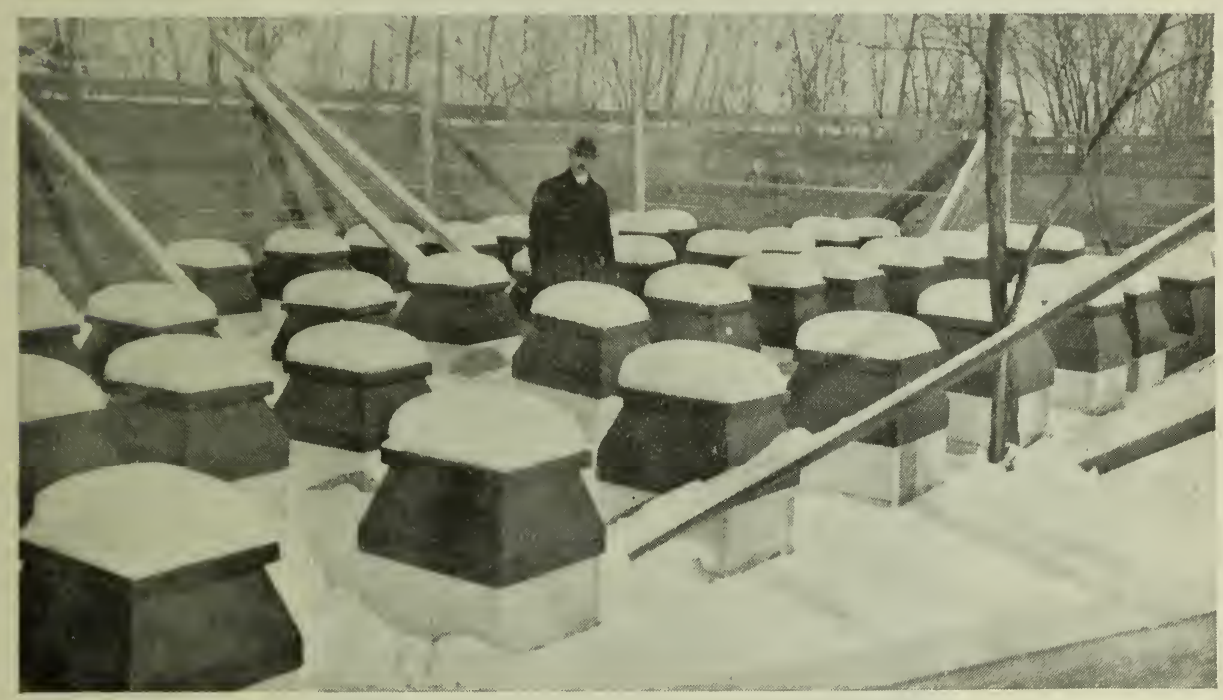

Fio. 17.-Apiary of Mr. J. Tissot, Ottawa. Mr. Tissot winters in double-walled hives and provides a good wind-break.

The bees should be removed from the cellar either in the evening, early morning, or on a dull day when there is little possibility of an immediate flight. Close the entrances of the colonies when bringing them out and when this temporary filling is removed, reduce the entrances to about two inches, in order to conserve the heat of the colony and to prevent robbing.

The colonies may be examined on a warm day when the bees are flying freely. Those having less than fifteen or twenty pounds of stores should be fed sugar syrup or, better still, combs of honey saved from the previous year's crop. Never equalize stores unless the apiary is free from disease and never feed honey from an unknown source. A good beekeeper seldom has to bother with spring feeding; he does sufficient feeding in the fall. Colonies that are queenless or have drone-producing queens, should be united to other colonies having fertile queens. Any failing queens should be replaced at once. Very weak queen-right colonies may be saved by placing them over strong colonies with a queen-excluder between, for a few weeks, or they may be strengthened by adding package bees. 
It is wise to defer this first examination until after a few days of favourable weather conditions and nectar is coming in freely. During their first flight after the winter the bees of the different colonies mix considerably, especially if strong winds blow through the apiary, and large numbers of strange bees in the hive with no nectar coming in are liable to cause the queens to be attacked, balled and possibly killed if the colony is opened. Also the presence of a fertile queen can more readily be ascertained if the examination is put off until there is capped brood. Further, there is a great risk of brood getting chilled during early examination than when the weather is warmer. Outdoorwintered bees may be examined while still in their cases.

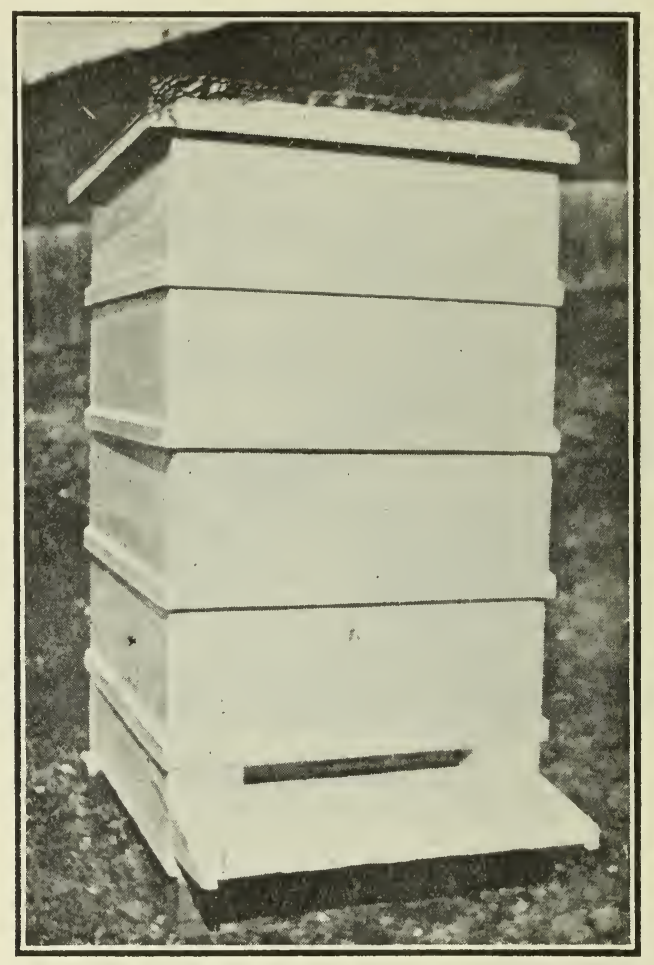

Fig. 18.-Kootenay case assembled.

(Courtesy of W. J. Sheppard, Provincial Apiarist, British Columbia)

Bees need large quantities of water during the spring, when brood rearing is going on, therefore, if there is no stream near the apiary, and to prevent the bees from going long distances for it, water should be supplied in some sheltered spot in the apiary.

A second examination will not be necessary for two or three weeks, especially if the weather does not warm up rapidly and new nectar and pollen are not abundant. At the second examination, watch for brood diseases. These can more readily be detected before the colony becomes populous. 


\section{SUMMARY}

In conclusion, we may repeat that the successful wintering of bees is one of the most important factors in Canadian beekeeping. Over the greater part of Canada the winter is usually long and very severe, making it necessary to provide conditions for the bees so that their life may be prolonged for more than the normal period. To be able to live through the long, cold winter months, the colonies must: first, be well filled with young bees at the commencement of the winter; second, be provided with an abundance of good wholesome stores, to last well into the following spring; and third, be given sufficient protection to prevent waste of energy and life in the production of heat. The means for obtaining these three conditions may be summarized as follows:

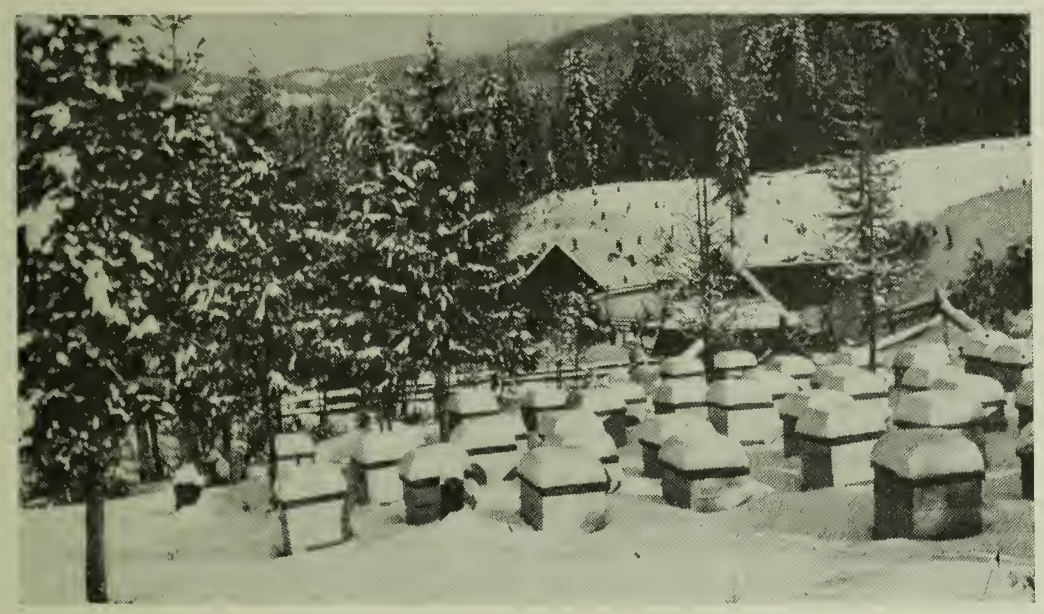

FIG. 19.-An apiary packed in Kootenay cases. (Courtesy of W? J. Sheppard, Provincial Apiarist, British Columbia.)

1. Each colony must be headed with a prolific queen at least 6 to 8 weeks before the normal cessation of brood-rearing in the fall.

2. The bees must be given at least 40 pounds of the best grade of honey or sugar syrup in the fall before the winter cluster is formed.

3. For outdoor wintering the bees must be packed in their cases early in the fall, and for cellar wintering they must be brought in before settled cold weather commences.

4. The cases for outdoor wintering must be large enough to hold sufficient packing in addition to the colonies and must also be tight to prevent the packing becoming wet.

5. The apiary must also be surrounded with a good wind-break.

6. The cellar must be well insulated from outdoor temperatures, so that the temperature may be kept within a range of from 45 degrees to 50 degrees $\mathrm{F}$.

7. It must also be kept dark; fairly dry; and provided with a good system of ventilation.

8. After being placed in winter quarters, the bees should not be disturbed.

9. Cellar-wintered bees should be left in the cellar until nectar and pollen are available in the spring; and outdoor-wintered bees left in their cases until the end of May or early June. 



\section{PUBLICATIONS ON BEE KEEPING}

The following publications of the Department of Agriculture relating to bee-keeping may be obtained, free of charge, by writing the Publications Branch, Department of Agriculture, Ottawa:-

Bee-kceping in Canada...................... Cir. 18

Bees and How to Keep Them.................... 33. N.S.

Wintering Bees in Canada................... Bul. 74, N.S.

Facts about Honey........................ Cir. 51 
